\title{
The People's Court: On the Intellectual Origins of American Judicial Power
}

Ian C. Bartrum

WIIliam S. Boyd School of Law, UNLV

Follow this and additional works at: https://ideas.dickinsonlaw.psu.edu/dlr

Part of the Administrative Law Commons, Agency Commons, American Studies Commons, Constitutional Law Commons, Courts Commons, Election Law Commons, First Amendment Commons, Fourteenth Amendment Commons, Fourth Amendment Commons, Intellectual History Commons, Judges Commons, Jurisdiction Commons, Jurisprudence Commons, Law and Philosophy Commons, Law and Politics Commons, Law and Society Commons, Legal History Commons, Legal Writing and Research Commons, Legislation Commons, Political History Commons, President/Executive Department Commons, Rule of Law Commons, Second Amendment Commons, and the Supreme Court of the United States Commons

\section{Recommended Citation}

Ian C. Bartrum, The People's Court: On the Intellectual Origins of American Judicial Power, 125 Dıck. L. REV. 283 (2021).

Available at: https://ideas.dickinsonlaw.psu.edu/dlr/vol125/iss2/2

This Article is brought to you for free and open access by the Law Reviews at Dickinson Law IDEAS. It has been accepted for inclusion in Dickinson Law Review by an authorized editor of Dickinson Law IDEAS. For more information, please contactlja10@psu.edu. 


\title{
Articles
}

\section{The People's Court: On the Intellectual Origins of American Judicial Power}

\author{
Ian Bartrum*
}

\section{Abstract}

This article enters into the modern debate between "constitutional departmentalists"-who contend that the executive and legislative branches share constitutional interpretive authority with the courts-and what are sometimes called "judicial supremacists." After exploring the relevant history of political ideas, I join the modern minority of voices in the latter camp.

This is an intellectual history of two evolving political ideas-popular sovereignty and the separation of powers-which merged in the making of American judicial power, and I argue we can only understand the structural function of judicial review by bringing these ideas together into an integrated whole. Or, put another way, we must expand the traditional conception of the "separation of powers" to include not just distinct institutional functions, but also the structured division of the sovereign pre-

\footnotetext{
* Professor of Law, William S. Boyd School of Law, UNLV. Thanks to Akhil Amar, Randy Barnett, George Dent, Ray Diamond, Sanford Levinson, Frank Michelman, George Mocsary, David Tanenhaus, Alex Tsesis, Gordon Wood and to Dane Smith and Paige Hall for their valuable comments and research assistance. Thanks also to participants in the AALS Panel on Judicial Supremacy, Loyola (Chicago) Constitutional Law Colloquium, the University of Arizona Constitutional Law Symposium.
} 
rogative itself, both within and without the institutions of government. It then becomes possible to read Article III as part of a larger effort to unbundle the metaphorical sticks of traditional sovereign power, and to vest what I call the revolutionary prerogative in an independent judicial branch.

This prerogative establishes an institutional form through which the Court might invoke John Locke's famous "revolution principle" on behalf of the sovereign People. It thus allows for what James Wilson celebrated-and what Sir William Blackstone could not conceive-the possibility of legalized revolution. In other words, the revolutionary prerogative allows for formal, independent appeal of the terms of the constitutional contract, by which the People delegated limited and contingent authority to their legislative and executive agents. Indeed, it is the final legal step before constitutional amendment or dissolution. Of course, the People retain the ultimate sovereign prerogative to declare the state of exception, but once constituted, the meaning of our fundamental law remains firmly, and solely, a matter of judicial discretion.

\section{TABLE of Contents}

INTRODUCTION .................................. 284

I. Two Enlightened IdeAs . . . . . . . . . . . . . . 287

A. Popular Sovereignty..................... 288

B. Separation of Powers ...................... 300

II. The American Federalists .................. 329

A. Popular Sovereignty: James Wilson ............ 329

B. Separation of Powers: Adams and

Hamilton.................................. 334

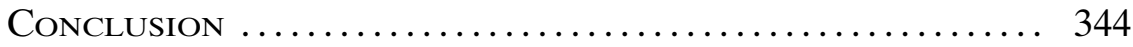

\section{INTRODUCTION}

Recent scholarship has shed considerable light on the intellectual traditions that informed our Constitution's framers and ratifiers as they took up their unprecedented work in the late 1780s. ${ }^{1}$ In particular, Michael McConnell's illuminating study of the structure of Article II is a remarkable addition to our understanding of historical ideas about the relationship between legislative and executive authority. ${ }^{2}$ At this moment, with our "so-called judge[s]" under renewed scrutiny-and a President who has openly

1. See, e.g., Noah Feldman, The Intellectual Origins of the Establishment Clause, 77 N.Y.U. L. REv. 346 (2002); Michael McConnell, The Logical Structure of Article II, (draft, on file with author).

2. McConnell, supra note 1. 
threatened to defy the Supreme Court-it is worthwhile, I think, to explore the intellectual history of our Article III courts. ${ }^{3}$ In what follows, I revisit the history of ideas that informed the American creation of an independent judiciary equipped with the power of judicial review.

There is, of course, already an excellent historical literature on the development of the judiciary as a distinct and independent source of political authority. ${ }^{4}$ Much of this literature, however, confines itself, at least primarily, to the origins and evolution of ideas about the formal separation of institutional powers-looking principally to Montesquieu, John Adams, and their forebears-and considers contemporary historical conceptions of popular sovereignty only incidentally. Likewise, there is a robust and fascinating literature on the history, theory, and practice of popular sovereignty in early America. Though much of this work touches upon the separation of powers, there is less sustained attention to the substantial role that conceptions of institutional structure played in bringing this foundational political premise to life. ${ }^{5}$

This article suggests that these two evolving political ideaspopular sovereignty and the separation of powers-merged in the making of American judicial power, and that it is impossible fully to understand the structural function of judicial review without weaving these strands together into an integrated whole. Or, put another way, we must expand the traditional conception of the "separation of powers" to include not just distinct institutional functions, but also the structured division of the sovereign prerogative itself, both within and without the institutions of government.

3. See Maggie Haberman, Trump's Brand of Law and Order Leaves Leeway on the Law, N.Y. Times (Aug. 27, 2017), https://nyti.ms/31CCGXj [https://perma.cc/ $6 \mathrm{PVV}-\mathrm{U} 5 \mathrm{KW}$ ]; see also Elliot Hanon, Trump Expected to Defy Supreme Court and Announce Executive Action on Census Citizenship Question, Slate (July 11, 2019), https://bit.ly/36Vywpx [https://perma.cc/MJ2U-HE29]; Adam Liptak, Roberts Rebukes Trump for Swipe at 'Obama Judge,' N.Y. Times, Nov. 22, 2018, at A1.

4. See generally, e.g., Philip Hamburger, Law and Judicial Duty (2008); Scott Douglas Gerber, A Distinct Judicial Power: 1606-1787 (2011); Scott Gordon, Controlling the State: Constitutionalism From Ancient Athens to Today (1999); Kurt von Fritz, The Theory of the Mixed Constitution in Antiquity (1975); M. J. C. Vile, Constitutionalism and the Separation of Powers (1967); E.G. Panagopoulos, Essays on the History and Meaning of Checks and Balances (1985); Charles McIlwain, Constitutionalism Ancient and Modern (2010); Eugene V. Rostow, The Sovereign Prerogative: The Supreme Court and the Quest For Law (1963); Harold Berman, Law and Revolution: The Formation of the Western Legal Tradition (1983).

5. Scott Gordon's excellent book comes perhaps the closest to weaving these political ideas together into a coherent whole. See Gordon, supra note 4, at 19-51. His work is not focused directly on judicial power, however. 
With this in mind, we must read Jean Bodin, Locke, and Wilson alongside Aristotle, the English Civil War theorists, Blackstone, and the Federalists. Once this marriage is made, it becomes evident that the institutional separation of judicial power provides the necessary architecture for an American practice of popular sovereignty, and it is together that these intellectual traditions underwrite our constitutional commitment to the rule of law.

With these theoretical threads spun together across time, Article III becomes part of a larger effort to unbundle the metaphorical sticks of traditional sovereign power, and to vest what I call the revolutionary prerogative in an independent judicial branch. This prerogative establishes an institutional form through which the Court might invoke Locke's famous "revolution principle" on behalf of the sovereign People. It thus allows for what James Wilson celebrated-and what Sir William Blackstone could not conceivethe possibility of legalized revolution. ${ }^{6}$ In other words, the revolutionary prerogative allows for formal, independent appeal of the terms of the constitutional contract, by which the People delegated limited authority to their legislative and executive agents. Indeed, it is the final legal step before constitutional amendment or dissolution.

While Professor McConnell was able to undertake a blow-byblow examination of the text and commentary of the founding to reveal the redistribution of prerogatives between executive and legislative institutions, there is very little similar record to exploit regarding the nature of the sovereign authority delegated to the third branch. Thus, this article turns to an older intellectual history of political writings, and concludes that the revolutionary prerogative-the discretion to declare the "law of the land" as against political officials-came in America to belong to an independent judicial branch. ${ }^{7}$ The People and the President retain a concurrent

6. See discussion infra notes 328-332 and accompanying text.

7. To be quite clear, then, I do not explore the "original meanings"-public, intended, expected, or otherwise-of Article III. As Gordon Wood and many others have pointed out, there was a broad diversity of opinion on the propriety of judicial review at the founding. Gordon S. Wood, The Origins of Judicial Review Revisited, Or How the Marshall Court Made More Out of Less, 56 WAsH. \& LeE L. REv. 787 (1999). And certainly, many founders, notably Jefferson and Madison, rejected claims that the Court had exclusive power to interpret the Constitution. Id. at 795-96. This, then, is not an "originalist" paper in the parlance of our times. Rather, I attempt to use intellectual historical sources to better understand the structural relationships (intended, expected, or otherwise) that our written Constitution establishes between the People, Congress, the President, and the Court. Further, I make no claim here about particular applications of this intellectual history to any modern legal controversies. In that sense, I am interested only in the 
prerogative of final appeal in non-constitutional cases (through jury nullification and the pardon power), but even a pardon cannot alter the judiciary's determination of constitutional meaning. ${ }^{8}$ Just because the President has set Sheriff Joe Arpaio free does not render his actions in office constitutional. Of course, the People retain the ultimate sovereign prerogative of constitutional amendment or dissolution, but once constituted, the meaning of our fundamental law remains firmly, and solely, a matter of judicial discretion. ${ }^{9}$

\section{Two EnLightened Ideas}

In the 1600 s, as the early triumphs of the scientific method stirred the dormant European mind, a swell of humanist naturalism began to wash through the dogmatic corners of academic scholasticism. ${ }^{10}$ Rapid advances in our ability to understand and to predict the natural world brought renewed optimism about our capacity to find order in ancient chaos, and, perhaps, to discover perspicuous principles upon which to found political institutions grounded in justice and consent, rather than superstition and fear. In this fertile ground, modern political theory began to take root: social contract theorists like Hobbes, Locke, and Rousseau; structuralists like Contarini, Montesquieu, and Adams; critical humanists like Diderot, Voltaire, and Hume; and progressives in the mold of Condorcet, Helvetius, and Godwin - among many others-rubbed intellectual elbows in a newly scientific academy. ${ }^{11}$ It is here that the ideas that shaped the American Constitution began to take on their modern forms. My object is not to revisit the daunting whole of this blossoming liberalism, but rather to trace the development of two particular constitutional ideas: popular sovereignty and the separation

history of ideas, and decidedly not in discrete modern legal meanings. See Lawrence Solum, Intellectual History as Constitutional Theory, 101 VA. L. REv. 1111 (2015); Saul Cornell, Intellectual History as an Alternative to Originalism, 82 FORDHAM L. REv. 721 (2013).

8. See, e.g., United States v. Klein, 80 U.S. 128 (1871) (addressing the effect of a pardon on statutory interpretation, but the reasoning applies a fortiori to constitutional interpretation).

9. I thus enter-at least partly—into the current debates over "constitutional departmentalism" and "judicial supremacy" decidedly in support of the latter position. See, e.g., Richard H. Fallon, Jr., Judicial Supremacy, Departmentalism, and the Rule of Law in a Populist Age, 96 Tex. L. Rev. 487 (2018) (discussing the canvassing debate).

10. Humanist naturalism seeks metaphysical answers in empirical observations of the natural world and suggests that human beings have the capacity to make these discoveries for themselves.

11. For a fascinating take on Enlightenment political theories-and subsequent revisionism - see Peter Gay, The Enlightenment in the History of Political Theory, 69 Pol. SCI. Q. 374, 375-78 (1954). 
of powers. I examine each tradition separately before outlining how they came together to produce a constitutionally independent judiciary.

\section{A. Popular Sovereignty}

A number of modern scholars-among them Bruce Ackerman, Akhil Reed Amar, Randy Barnett, and Barry Friedman-have built more or less comprehensive theories of American constitutionalism around various conceptions of popular sovereignty. ${ }^{12}$ And, recently, the intellectual history of the doctrine has been the subject of renewed interest, with important new treatments by Richard Tuck and Daniel Lee going to press in just the last few years. ${ }^{13}$ The basic idea, however, remains fairly straightforward, even if it was still somewhat radical in the late 18th century. It is the People, in some form, that retain sovereignty in a constitutional republic. ${ }^{14}$ They may, in various ways, authorize public institutions to exercise certain powers, but they retain the ultimate prerogative to, as Carl Schmitt would famously put it, "decide[] upon the exception." 15

As with any political theory, of course, the devil is in the details. Who are the People? How can they be both sovereign and subject? How do they delegate authority? What authority can they delegate or reserve? How do they exercise their retained prerogative? How do we account for dissent? These and other questions have puzzled theorists since the early days of the republic-and, indeed, for centuries before. ${ }^{16}$ In this section, I trace the basic prin-

12. See Bruce Ackerman, We the People: Foundations (1991); Akhil Reed Amar, Of Sovereignty and Federalism, 96 YALE L.J. 1425 (1987); RANDY Barnett, The Lost Constitution (2004); Barry Friedman, The Will of the People (2009).

13. See generally, e.g., Daniel Lee, Popular Sovereignty in Early Modern Constitutional Thought (2016); Popular Sovereignty in Historical Perspective (Richard Bourke \& Quentin Skinner eds., 2016); Richard Tuck, The Sleeping Sovereign (2015).

14. See, e.g., James Wilson, Introductory Lecture: Of the Study of the Law in the United States, in 1 Collected Works of James Wilson 431, 445-46 (Kermit Hall \& Mark David Hall eds., 2007) [hereinafter Wilson, Of the Study of the Law]. Accord James Wilson, State House Yard Speech (Oct. 6, 1787), in 1 ColLECTED Works OF JAMES Wilson, supra, at 171.

15. On delegated sovereignty, see James WiLson, State House Yard Speech (Oct. 6, 1787) in 1 Collected Works of JAMEs Wilson, supra note 14, at 171. On the essence of sovereignty, see Carl Schmitt, The Concept of the PolitiCAL 19 (George Schwab trans., expanded ed. 2007) ("Sovereign is he who decides upon the exception.").

16. Indeed, Edmund Morgan has famously argued that much of the theory that underwrites the Anglo-American political nomos amounts to "fictional" or 
ciple from its classical roots to the American founding, with an emphasis on the role that judicial institutions play in various conceptions. I conclude that, on the eve of the American Revolution, the conceptual pieces were available to lodge a legalized power of revolution in the courts.

1. Aristotle - There will be more to say about Aristotle in discussing the separation of powers, but the Politics deserves at least a brief mention here, too, if only to establish its influence in the debates to follow. ${ }^{17}$ Aristotle never developed a discrete theory of popular sovereignty, but his fundamental ideas about the nature and purpose of politics undoubtedly laid the foundation for later work. ${ }^{18}$ Most salient in this regard are his teleological accounts of man as the "political animal," and his assertion that the final cause of politics is human fulfillment and the good life. ${ }^{19}$ Though he never drew it, it is easy to imagine a fairly straight line between these underlying premises and the conclusion that mankind can, and must, govern itself. That is, if the purpose of politics is to make fulfilling lives possible, and if humans are political by nature, then the state's very purpose is to give citizens a meaningful role in shaping their own political destinies. Certainly Aristotle shared little of the modern American optimism about everyone's ability to understand and practice political virtue, and so we cannot attribute to him a general theory of popular governance. ${ }^{20}$ But here at least is an account of human, rather than divine, political authority-one which locates at least some of that authority in the will of the governed themselves. In the years to come, as medieval humanists pushed back against overreaching Papal authority, Aristotle's ideas would provide substantial grist for the theoretical mill.

2. Marsilius of Padua - Marsilius was an Italian scholar, trained as a physician, who would rise to become Rector of the Uni-

"mythological" kinds of narrative. Edmund S. Morgan, Inventing the People: The Rise of Popular Sovereignty in England and America (1988).

17. Aristotle, Politics (C. D. C. Reeve trans., Hackett Publ'g Co. 1998) (c. 350 B.C.E.) [hereinafter Politics].

18. Indeed, it seems that the prevailing modern view considers it "anachronistic" to impute anything like a modern conception of "sovereignty" to the ancient Greeks. See Kinch Hoekstra, Athenian Democracy and Popular Tyranny, in Popular Sovereignty in Historical Perspective, supra note 13, at 15.

19. Politics 1. 1252b 30-31 ("[T]he state comes into existence, originating in the bare needs of life, and continuing in existence for the sake of a good life."); id. at 1253a 2-3 ("Hence it is evident that the state is a creation of nature, and that man is by nature a political animal.").

20. Id. at 1254a 22-23 ("[F]rom the hour of their birth, some are marked out for subjugation, and others for rule."). 
versity of Paris in 1313. ${ }^{21} \mathrm{He}$ was a disciple of "the divine Aristotle," upon whom he relied throughout his efforts to challenge the Vatican's temporal authority. ${ }^{22}$ Marsilius's great work, Defensor Pacis, is in large part a theological discourse, but it also establishes some of the early groundwork for popular sovereignty theory. ${ }^{23}$ Pointing again and again to Aristotle, Marsilius argued that coercive legal authority ultimately derives from the people themselves: "[I]t pertains to the whole body of the citizens to generate the form, that is, the law, according to which all civil acts must be regulated." 24 This "whole body of citizens" he identified as the "primary legislator," the legislator humanus, which he carefully distinguished from "the ruler," or principatus, who must act in "accordance with the form which the legislator has given to him." 25

While this much is roughly consistent with Aristotle, Marsilius went on to make an even stronger claim: The citizens, themselves, are in fact the only source of legitimate coercive authority:

The aforesaid whole body of citizens or the weightier part thereof is the legislator regardless of whether it makes the law directly by itself or entrusts the making of it to some person or persons, who are not and cannot be the legislator in the absolute sense, but only in a relative sense and for a particular time and in accordance with the authority of the primary legislator. ${ }^{26}$

Here, then, is the germ of modern popular sovereignty doctrine. Not only are citizens the source of legitimate coercive power; they further retain the sovereign prerogative as primary legislator-even when they delegate certain authority to rulers or government institutions.

For Marsilius particularly, the important point was that the authority to impose coercive law lies with the People, not the Pope or his interpretations of divine will. ${ }^{27}$ Indeed, he argued that the

21. Alan Gewirth, Introduction to Marsilius of Padua, Defensor Pacis xix, xix (Alan Gewirth trans., 1967).

22. Id. For the quoted phrase, see Marsilius of Padua, Defensor Pacis 38 (Alan Gewirth trans., Columbia Univ. Press, 1967) (1324) [hereinafter DefenSOR PACIS].

23. See generally Defensor PACIS, supra note 22.

24. Id. at 62.

25. Id. (emphasis added).

26. Id. at 45 ; see also id. at 46 ("[T] $\mathrm{T}$ he human authority to make laws belongs only to the whole body of the citizens or the weightier part thereof.").

27. Generally, the second discourse is a vitriolic protest against the encroachments of Papal authority, which led to Marsilius's excommunication in 1327. Serena Ferente, Popolo and Law: Late Medieval Sovereignty in Marsilius and the Jurists, in Popular Sovereignty in Historical Perspective, supra note 18, at 96, 98. 
Church was structurally precluded from playing an active role in governing temporal affairs. ${ }^{28}$ Thus, while Marsilius did not hold modern views about the institutional separation of political powers, he certainly did suggest that the functions of church and state must remain separate in fundamental ways. ${ }^{29}$ This in itself is quite significant, as some see the genesis of modern separation of powers theory in these early efforts to delineate the proper boundaries of religious and civil authority. ${ }^{30}$

Marsilius also offered some limited thoughts on judicial power and its relationship to the sovereign. Certainly, he did not conceive of an independent or structurally separate judicial branch of the state. Once the legislator empowers the ruler through law, the latter has univocal authority to carry out his delegated prerogativesso long as his actions basically conform to the legislative command. ${ }^{31}$ But Marsilius was not naive to the fact that the ruler is a "human being" susceptible to "false opinion[s] or perverted desire[s] or both, as a result of which he comes to do the contraries of the things determined by the law." 32 This reality requires that "the ruler is rendered measurable by someone else who has the authority to measure or regulate him." 33 For Marsilius, this must be done by "the legislator, or by a person or persons appointed for this purpose by the authority of the legislator." 34 He stopped short of calling these appointees "judges" 35 - they are instead a manifestation of the People as sovereign legislator-but here at least is an inkling of the corrective doctrine that would much later become judicial review.

3. Jean Bodin - While other late medieval scholars-perhaps most notably John of Segovia-pushed Marsilius's ideas forward, the next significant evolution in popular sovereignty theory emerged from the work of Renaissance philosopher Jean Bodin. ${ }^{36}$

28. See Defensor Pacis, supra note 22, at 12-27 (quote p. 18).

29. Id. at $17,20$.

30. Berman, supra note 4, at 536-37.

31. Defensor PACIS, supra note 22, at 87.

32. $I d$.

33. Id.

34. Id. at 88 .

35. Indeed, there is a strong case to be made that Marsilius saw the ruler as merely the "judge" of conduct prescribed by the popular legislator. See Tuck, supra note 13, at 78 ("As far as Marsiglio was concerned the legislator humanus monopolized legislation, and the principatus was merely a judge . . .."); accord Alan Gewirth, Marsilius of Padua and Medieval Political Philosophy 234 (1951) ("For Marsilius, political authority is unilinear: it moves in a straight line from the legislator to the ruler who judges by authority of the legislator ....").

36. For an exceptional treatment of other late medieval sovereignty theorists, see generally LEE, supra note 13 . 
A French lawyer, academic, and magistrate, Bodin came of age during the Reformation, and-like Hobbes after him-he argued that a strong monarchy provides the best civil protection against factional religiosity and unrest. ${ }^{37}$ As such, he was an adamant critic of Aristotle's mixed regime, particularly inasmuch as it lent support to Protestant calls for various forms of popular government. ${ }^{38}$ Presumably this criticism would extend to the Aristotelian Marsilius, although in truth there is no evidence that Bodin ever read Defensor Pacis. ${ }^{39}$ Perhaps ironically, however, from these absolutist critiques arose Bodin's substantial contribution to modern democratic theory: an explicit distinction between sovereignty and government. ${ }^{40}$

Aristotle's failure to recognize this distinction, Bodin claimed, led him to conflate the sovereign prerogative with state authority, thus endowing "the few" and "the many" with a fundamental dominion they did not possess. ${ }^{41}$ It was a mistake to suppose that conceding "the right of deliberation about the state . . . even to private citizens, and the administration of justice to the humblest man" rendered these actors sovereign. ${ }^{42}$ To the contrary, this was clear evidence that such supervisory duties "do not pertain to sovereignty," but rather to the administration of government. ${ }^{43}$ To discover the true sovereign power, or summum imperium, we must instead "investigate who can give authority to magistrates, [and] who can take it away." 44 This ultimate authority, both "absolute and perpetual" 45 necessarily enjoys "supreme power over citizens

37. This, at least, is the view of Julian Franklin, the leading 20th century Bodin scholar. Julian Franklin, Jean Bodin and the Rise of Absolutist TheORY (1973); accord, William Dunning, Jean Bodin on Sovereignty, 11 PoL. SCI. Q. 82,87 (1896).

38. Tuck, supra note 13, at 29-30.

39. Id. at 78 .

40. Jean Bodin, The Six Books of a Commonweale (Six Livres de la Republique) 249 (Kenneth D. McRae ed., Harvard Univ. Press 1962) (Richard Knolles trans., 1606) (1576) [hereinafter RePublique]; accord TucK, supra note 13, at 30. Bodin would label these distinct entities summum imperium and administratio, which "would henceforward remain the standard way of describing the distinction between the 'sovereign' and the 'government' in the Latin texts of Renaissance and post-Renaissance Europe." Id.

41. Jean Bodin, Method for the Easy Comprehension of History (Methodus ad Facilem Historiarum) 156 (Beatrice Reynolds trans., W.W. Norton \& Co. 1969) [hereinafter Methodus].

42. $I d$.

43. $I d$.

44. Id. at 178 .

45. Jean Bodin, On Sovereignty 1 (Julian H. Franklin trans. \& ed., Cambridge Univ. Press 1992) (assembling selections from the RePubliQue) [hereinafter Bodin: On Sovereignty]. 
and subjects, unrestrained by laws." ${ }^{46}$ And it is only by identifying the locus of this power-in which Aristotle had failed-that we can properly identify the nature of a particular state:

[The sovereignty] distinction nonetheless seems to me more than necessary, for the good understanding the state of every commonwealth, if a man will not cast himself headlong into an infinite labyrinth of errors, where into which we see Aristotle himself to have fallen, mistaking the popular commonwealth for the aristocratic one and vice versa; . . From this error likewise is sprung the opinion of them which have forged a form of commonwealth mingled of all three types . . . ${ }^{47}$

By "absolute," Bodin meant, among other things, that the sovereign power is indivisible, although this did not prevent the sovereign from delegating its authority "in any way it pleased." 48 The fundamental point was that such delegates remain agents, who can "never [themselves] be sovereign." 49 Further, the sovereign, as principal, retains the right to reclaim its delegated authority at any time. ${ }^{50}$ This, in turn, is the significance of the "perpetual" nature of sovereign authority-as opposed to the agencies of government, whose "grasp on such extraordinary power is always temporary and tenuous." 51 While Bodin's intention may have been to defend the ultimate authority of the French monarchy against the Estates-General, he had no theoretical objection to the possibility of a popular or democratic sovereign. ${ }^{52}$ Again, the critical insight is the principal-agency relationship between the sovereign and its delegated officers, an idea Bodin found rooted in the Roman civil law tradition. ${ }^{53}$ Those that followed Bodin's lead-particularly the German Christopher Besoldus-would analogize this relationship

46. Dunning, supra note 37, at 92.

47. RepubliQue, supra note 40, at 249-50 (archaic usages modernized).

48. For the quotation, see LeE, supra note 13, at 195. In the Methodus, Bodin outlined five essential features or "marks" of sovereignty:

One ... is creating the most important magistrates and defining the office of each one; the second, proclaiming and annulling laws; the third, declaring war and peace; the fourth, receiving final appeal from all magistrates; the last, the power of life and death when the law itself leaves no room for extenuation or grace.

Methodus, supra note 41 at $172-73$.

49. LEE, supra note 13, at 199 ("[T] he main point that Bodin wanted to stress was the incompatibility of sovereignty and agency ....").

50. Id.

51. Id.

52. Tuck, supra note 13, at 50. Tuck notes that Bodin was, however, hostile to the idea of a democratic government, which might easily descend into demagoguery.

53. LEE, supra note 13, at 200-05. 
to the distinction between "real" and "personal" property: "real" or immovable sovereignty lies with the principal, who may delegate temporary "personal" sovereignty to his agents. ${ }^{54}$ In future years, this "real-personal" distinction would become an essential feature of evolving popular sovereignty theory-one that English theorist George Lawson, among others, would adopt in the aftermath of the English Civil War. ${ }^{55}$

Perhaps just as interesting, for present purposes, are Bodin's efforts to explain the peculiar intermediary authority of the French Parlements, particularly in their role as the nation's highest courts. $^{56}$ By Bodin's reckoning, such bodies-while certainly not sovereign-could bind the king to his promises as a matter of duty:

[A] sovereign prince is bound by the contracts he has made, whether with his subject or with a foreigner .... Thus the Parlement of Paris wrote to King Charles IX in March 1563 that his majesty could not unilaterally break the contract between himself and the clergy without the clergy's consent, inasmuch as he had a duty to give justice .... [Likewise, the sovereign] cannot take away an office he has given to his subject without just cause, which a private lord can do, as the courts have ordinarily adjudged. ${ }^{57}$

Further, there could be no appeal from the judgment of a Parlement sitting as a court-and similar judicial institutions existed in virtually all European states. ${ }^{58}$ Taken together, these practices seemed to suggest: (1) that the sovereign can be bound by some form of law, in which case, his authority was not absolute; and (2) that the right of final appeal is not, as was universally supposed, "one of the principal rights of sovereignty." 59

Bodin's response to these suggestions was to argue: (1) that sovereign promises (even contracts) are not enforceable as a matter of law, but rather as a matter of obligation; and that (2) in every

54. See, e.g., Julian H. Franklin, John Locke and the Theory of SovEREIGNTY 64-68 (1978) (discussing the distinction's emergence and use among post-Bodinian thinkers).

55. Id.; see also infra notes $224-50$ and accompanying text.

56. See Tuck supra note 13, at 59-61.

57. Bodin: On Sovereignty, supra note 45, at 35. See also, Lee, supra note 13 , at 213 ("[W]hile the sovereign authority may be exempt from its own laws, legibus solutus, it is not exempt from its contractual obligations, especially where those obligations arise from legal grants of office to magistrates.").

58. Bodin: ON SovereignTy, supra note 45 , at 68 ("[I]n every state one finds courts and Parlements that judge without appeal, such as the eight Parlements of France, the four Courts in Spain, the Imperial Chamber in Germany, the Council at Naples, the Rota at Rome, and the senate at Milan.”).

59. Id. at 67, 69. 
state there remains an implied right of civil petition to the sovereign, even following the judgment of the highest court. ${ }^{60}$ Nonetheless, he understood, as Richard Tuck has put it, that the "balance between King and Parlements could not be expressed by saying that the Parlements were agents of the King, because the whole point of the system is that they were not." ${ }^{1}$ Thus, Bodin developed a theory of "constituted magistrates," whereby some legally established officers entered into a "binding bilateral obligation" with the sovereign. ${ }^{62}$ In Daniel Lee's words,

On the one hand, [such a] magistrate is bound by his obligation to the sovereign, as a sort of "borrower" of the public office and its imperium, to exercise it in good faith as well as to lay down and return the office to the sovereign upon completion of his legally specified term of office. Yet, so too is the sovereign bound by an obligation to the magistrate, by a duty of non-interference. In a government where offices are constituted by the law, the sovereign authority must not interfere in the affairs of the magistrate or remove the magistrate without cause. ${ }^{63}$

With these efforts to work out the nature of delegated sovereign authority, Bodin helped bring about another important development in the intellectual history of independent judicial power.

4. The Social Contract: Hobbes \& Locke - Bodin's sovereignty distinction initially met with some resistance on the European continent, particularly in the work of Hugo Grotius and Samuel Pfufendorf. ${ }^{64}$ In England, however, where the Republique was translated and printed in 1606, Bodin's ideas undoubtedly brought some comfort to a young Thomas Hobbes. ${ }^{65}$ Born as the Spanish Armada approached the island in 1588, and raised during the ensuing religious wars, he would later recall (in autobiographical verse), "hereupon it was my Mother Dear, Did bring forth Twins at once, both Me, and Fear." 66 For the young Oxford student, Bodin's prescription for religious and civil unrest-a supreme

60. Id. at 35-36, 69-70. "Obligation" arises from the law of nature or God, not the laws of men, from which the sovereign is exempt. $I d$.

61. Tuck, supra note 13, at 61.

62. LEE, supra note 13, at 213.

63. $I d$.

64. Tuck, supra note 13, at 63-64.

65. LEE, supra note 13, at 306. For a rich account of the larger shift from the mythology of "divine right" to the narrative of the "popular sovereign" as a stabilizing ethos, see Morgan, supra note 16, at 88-93.

66. Thomas Hobbes, The Life of Thomas Hobbes of Malmesbury, Written himself In a Latine Poem, and now Translated into English 2 (1680). 
and indivisible sovereign-must have struck a soothing chord. And in his efforts to account for how such a sovereign might come into being, Hobbes brought an old political idea to bear: the social contract.

Hobbes's ideas placed him somewhere between the opposing sides in the English Civil War-discussed in depth below-which dominated national politics during his later life. Unlike the Royalists, he rejected sovereignty by divine right (at least in a Christian nation), but he also rejected the Parliamentarian's view of a shared legislative prerogative. ${ }^{67}$ Instead, he envisioned a powerful absolute monarch-in the best Bodinian tradition-which derived her sovereignty not from God, but from an original contract with the people. $^{68}$ In fleshing out the nuances and entailments of this contract, Hobbes drew a careful, and crucial, distinction between potentially ambiguous references to the "the people." To be precise there are the "People," and the "people"-the former are sovereign, while the latter are subjects:

Whenever we say that a People or a number of men is willing, commanding or doing something, we mean a commonwealth which is commanding, willing and acting through the will of one man or through the wills of several men who are in agreement .... But whenever something is said to be done by a number of men, great or small, without the will of [the sovereign] man or meeting, it means it was done by a people as subjects, that is by many individual citizens. ${ }^{69}$

The sovereign, or the commonwealth, is thus univocal, even when it embodies the will of the People. Anything less than total unity is simply not sovereign authority, merely the multitudinous opinion of the subject citizenry.

Hobbes recognized that a large group of people cannot actually speak as one, and so the unity he described is possible only through representation. ${ }^{70}$ Sovereignty, he insisted, is an abstract or "artificial" concept, which cannot become tangible until made man-

67. For an excellent and thought-provoking account of Hobbes's relationship to his contemporary theorists, see Eleanor Curran, A Most Peculiar Royalist: Hobbes in the Context of His Political Contemporaries, 10 British J. Hist. Phil. 167 (2002).

68. Thomas Hobbes, De Cive, Ch. 5, §§ V-IX (1651).

69. Lee, supra note 13, at 310 (quoting Thomas Hobbes, De Cive, Ch. 6, $\S 1)$.

70. Thomas Hobbes, Leviathan I, 16, 14, 104 (Edwin Curley ed., Hackett 1994) (1651) ("And because the multitude is not one, but many . . . every man giv[es] their common representer authority from himself in particular, and own[s] all the actions the representer doth.") [hereinafter LeviATHAN]. 
ifest in a person or institution. ${ }^{71}$ We then imagine this person or institution as a "representation" of the sovereign will. ${ }^{72}$ The original covenant among the People brings this person or institution to life as the sovereign spirit instantiated, so resolving the apparent paradox in the (in)famous claim that, "the King is the people." 73 Perfect sovereign unity is thus a feature not of the represented, but of the representative. ${ }^{74}$ For Hobbes, of course, the best system of government is one in which the People give their unconditional and irrevocable sovereign consent to an absolute monarch, though he seemingly did not foreclose the possibility that sovereignty might be lodged - even temporarily or contingently-in democratic sorts of institutions. ${ }^{75}$

Hobbes's insistence on complete sovereign unity, however, would prevent him from signing on to Marsilius's or Bodin's fledgling ideas about courts and judicial review or constraint. Indeed, in a famous passage he explicitly rejected the idea of binding the sovereign to law, or of any appeal to the courts taken over the sovereign's head:

For to be subject to the laws is to be subject to the commonwealth, that is, to the sovereign representative, that is, to himself, which is not subjection, but freedom from the laws. Which error, because it setteth the laws above the sovereign, setteth also a judge above him, and a power to punish him, which is to make a new sovereign; and, again, for the same reason a third, to punish the second; and so continually without end, to the confusion and dissolution of the commonwealth. ${ }^{76}$

To empower a court to review sovereign action, in other words, simply transforms that court into the sovereign, and so on. To end this

71. $I d$. at 3 [Introduction] ("For by art is created that great LEVIATHAN called a COMMONWEALTH ... . which is but an artificial man ... in which the sovereignty is an artificial soul ..."); accord LEE, supra note 13, at 311.

72. Professor Lee emphasizes the deeply interesting point that "representation" in this sense "is not so much mimetic, but actively imaginative as in drama and liturgy." LEE, supra note 13, at 312.

73. Leviathan, supra note 70, at I, 16, 13 ("A multitude are made one person, when they are by one man, or by one person, represented so that it be done with the consent of everyone of that multitude in particular."). For the quotation, see Lee, supra note 13, at 311 (quoting Thomas Hobbes, De Cive, Ch. 12, § 8).

74. LeViathan, supra note 70, at I, 16, 13 ("For it is the unity of the of the representer, not the unity of the represented that maketh the person one... [A]nd unity cannot otherwise be understood in multitude.").

75. Richard Tuck is perhaps the most prominent advocate of this view. See, e.g., Richard Tuck, Hobbes and Democracy, in Rethinking the Foundations of Modern Political Thought (Annabel Brett, James Tully \& Holly HamiltonBleakley eds. 2006).

76. Leviathan, supra note 70, at II, 29, 9, 213 (emphasis in original). 
regression, Hobbes argued, we must declare that the sovereign is above the law-the power that makes the law cannot, by definition, be bound by it. And it was in response to these claims, as much as anything, that John Locke would make his most important contributions to liberalizing popular sovereignty theory.

Locke accepted Hobbes's social contract framework, but he envisioned the terms of the original agreement quite differently. Because God endowed us all with certain natural rights-at the very least, life itself-there are some powers we simply cannot consent away: "[F]or, as hath been said, no Man can, by agreement, pass over to another that which he hath not in himself, a Power over his own life."77 Thus, even as we enter political society we must hold in reserve those fundamental dignities that belong properly to God, with which we have no right or power to bargain. ${ }^{78}$ For this reason, Locke utterly rejected Sir Robert Filmer's absolutist claims-which went beyond even Hobbes's-suggesting that supreme and unconditional monarchy is "the only Government in the World." 79 With this rejection, Locke took a critical step forward in the western conception of limited government.

Locke argued that the concept of absolute monarchy is utterly inconsistent with our very reasons for entering into the social contract in the first place-and "so can be no form of Civil Government at all." 80 He imagined a state of nature considerably milder than Hobbes's, which in turn presented different motivations for entering into society. ${ }^{81}$ Rather than fear, the primary contractual incentive is the need for the neutral third-party appeal of property grievances. ${ }^{82}$ The sorts of absolute monarchy Filmer and Hobbes advocated permitted appeal of such disputes "that may happen betwixt the Subjects themselves," but offered no recourse for grievances against the sovereign itself. ${ }^{83}$ Such grievances might nonetheless be justified, Locke maintained, on grounds of the inalienable natural rights-notably private property-reserved from

77. John Locke, Two Treatises of Government II.4.24 285 (Peter Laslett ed., Cambridge Univ. Press 1988) (1689).

78. Id.

79. $I d$. at II.7.90 326.

80. Id.

81. Id. at II.4-6 269-71.

82. On neutral appeal as "the end of Civil Society," see id. at II.7.90 326. On property rights as the primary motivation, see id. at II.7.84 329 ("[W]hereas Government has no other end but the preservation of Property ... ").

83. Id. at II.7.93 328. 
the original contract. ${ }^{84}$ It was therefore absurd to imagine people entering into a covenant that failed to provide this basic protection:

As if when Men quitting the State of Nature entered into Society, they agreed that all of them but one, should be under the restraint of Laws, but that he should still retain all the Liberty of the State of Nature, increased with Power, and made Licentious by Impunity. This is to think that Men are so foolish that they take care to avoid what Mischiefs may be done to them by PoleCats, or Foxes, but are content, nay think it Safety, to be devoured by Lions. ${ }^{85}$

At first blush, this seems to suggest that a correct account of the original social contract must provide for some division of the traditional sovereign prerogative. That is, if the very purpose of the agreement is to establish a neutral appeal, including upon matters of inalienable right, then the contract itself must be appealable to a third party. ${ }^{86}$ Here, however, Locke hedged his institutional bets. This ultimate appeal, he reasoned, must be made to God-who of course retains her own prerogative-through the political mechanism that Hobbes feared most: revolution. ${ }^{87}$ Thus, the sovereign prerogative is never actually divided; it remains wholly with the People themselves, not their representative, at all times.

Locke did his best, however, to reassure readers that such revolutions must be rare and, perhaps more importantly, sanctioned in heaven. ${ }^{88}$ The very possibility of such revolt, however, should serve as a warning and corrective to the wise prince, who would do well not to abuse the authority entrusted to him. ${ }^{89}$ For if government should breach its delegated trust, law-making authority must necessarily revert to its sovereign source:

[W]hen by the Miscarriages of those in Authority, [the Legislative power] is forfeited; upon the forfeiture of their Rulers . . . it reverts to the Society, and the People have a Right to act as Supreme, and continue the Legislative in themselves, or erect a new Form, or under the old form place it in new hands, as they think good. ${ }^{90}$

84. An arrangement that stripped a man of these rights without recourse would render him the "Slave of an Absolute Prince," and, recall, we have no right to sell our God-given lives into slavery. Id. at II.7.92 327.

85. Id. at II.7.93 328 (emphasis in original).

86. Id. at II.29.222 412-13.

87. See id. at II, 14, 168, 379; II, 18, 207, 403-04.

88. See id. at II, 18, 207-09; II, 19, 223-25, 241-42.

89. See id. at II, 18, 209.

90. Id. at II, 19, 243. 
This would become known as the Lockean "revolution principle,"91 and it was just this unhappy condition that Thomas Jefferson claimed for the American colonists in the opening lines of his revolutionary appeal for independence from Britain. ${ }^{92}$ And it should thus be no surprise that the Americans would quickly seize upon these blossoming notions of liberal popular sovereignty for their own theoretical and political purposes.

\section{B. Separation of Powers}

The idea of dividing political authority among plural governing institutions has classical roots, but the particular conception underlying the American constitutional doctrine emerged principally from the English Civil War and the subsequent Restoration. ${ }^{93}$ It was this evolving English structure-including efforts to split an independent judicial power away from the traditional executive prerogative-which Montesquieu purported to describe in his 1748 Spirit of the Laws. ${ }^{94}$ But it was left to John Adams and the Americans to realize these ideas in a written constitutional model rooted in popular sovereignty. ${ }^{95}$ One result was an independent judicial branch vested with the revolutionary prerogative to enforce the popular sovereign's expressed will against its government agents. Rather than organize this discussion around particular individuals, this section focuses more generally on certain periods of intellectual development. Of course, a few individuals may dominate discussion of a given period, but my hope is to reveal a fairly coherent chronological evolution in the theory of the separation of powers, particularly in the years between the English Civil War and the American Constitution.

91. See discussion supra notes 88-90 and accompanying text.

92. See The Declaration of IndePendence para. 1 (U.S. 1776).

93. For excellent surveys of this history, see M.J.C. ViLE, Constitutionalism and the Separation of Powers (1967); W.B. Gwyn, The Meaning of the Separation of Powers (1965); William Bondy, The Separation of Governmental Powers: In History, In Theory, and in the Constitutions (1896); Scott Gordon, Controlling the State: Constitutionalism From Ancient Athens to Today (1999); Scott Douglas Gerber, A Distinct Judicial Power: The Origins of An Independent Judiciary, 1606-1787 (2011); Gerhard Casper, Separating Power: Essays on the Founding Period (1997); The Rule of Law and the Separation of Powers (Richard Bellamy ed., 2005).

94. See VILE, supra note 93, at 60-63 (discussing work of George Lawson); see also Charles de Secondat, Baron de Montesquieu, The Spirit of the Laws (Anne Cohler, Basia Miller \& Harold Stone eds. \& trans., 1989) (1748).

95. E.g., John Adams, Thoughts on Government, in 4 Works of JoHN ADAms 193 (Charles F. Adams ed., 1856) [hereinafter Adams, Thoughts on Government]. 
1. The Classical Mixed Regime - Again, we begin with Aristotle, although this time exploring an idea with which he is much more closely associated: the mixed regime. ${ }^{96}$ As his political theory was embedded within his general metaphysical and ethical philosophy, it is worth first summarizing a very brief Aristotelian worldview.

Aristotle's teleological metaphysics famously center on his four causes of being: (1) The material; (2) the formal; (3) the efficient; and (4) the final. ${ }^{97}$ In the case of a city-state, the material causes are individual citizens - perhaps organized into households or communities-and the nation's natural resources. ${ }^{98}$ The formal cause is the constitution, which need not be written, but which must provide "a certain ordering" of political life. 99 The efficient cause is the lawgiver or founder-the "megalopsychos" or "great-souled man"-which here is the great statesman. ${ }^{100}$ Most importantly, the city-state's final cause is to help bring about the good or noble life-a notion that pervades much of the Politics. ${ }^{101}$ In Aristotle's political theory, it is the presence or absence of this virtuous purpose that differentiates a healthy constitutional form from its corrupt counterpart. ${ }^{102}$

Promoting the "good life," of course, presumes an ethical theory, and here Aristotle built upon the foundations laid in his Nicomachean Ethics. ${ }^{103}$ In particular, he returned to earlier discussions of both universal and distributive justice. ${ }^{104}$ The former requires that the state focus entirely on the "common advantage" of its citizens, rather than the particular benefit of its rulers. ${ }^{105}$ The latter requires that the state bestow benefits on individuals in proportion to their particular merit or desert. ${ }^{106}$ Consistent with the virtuous "golden mean," Aristotle's state is thus neither wholly an economic enterprise aimed at wealth maximization, nor wholly de-

96. See Politics, supra note 17. B.C.E.).

97. See Aristotle, Metaphysics A.2 (C .D. C. Reeve trans., 2016) (c. 350

98. See Politics, III, 1, 1274a, 38-41; VII, 14, 1325b, 38-41.

99. Id. at III, $1,1274 \mathrm{~b}, 32-41$.

100. See id. at II, 12, 1273b, 32-33; VII, 4, 1325b, 40-1326a, 5 (likening the founder or lawgiver to a craftsman).

101. See, e.g., id. at III, 6, 1278b, 17-24; III, 9, 1280b, 39; VII, 2, 1325a, 7-10.

102. See id. at III, 6, 1279a, 17-21.

103. See Aristotle, Nicomachean Ethics (Terence Irwin trans., Hackett Publ'g Co. 2d ed. 1999) (c. 350 B.C.E.)[hereinafter Ethics].

104. Id. at V, 1, 1129b, 11-19; V, 3.

105. Politics, supra note 17, at III, 12, 1282b, 16-17.

106. See id. at III, 9, 1280a, 7-22. 
voted to maximizing social equality and individual liberty. ${ }^{107}$ Rather, in a kind of dialectic, it demands a virtuous dedication to bringing about the good life for the whole, and it rewards with wealth, honor and status those who actively demonstrate this virtue. ${ }^{108}$

With these foundations in place, Aristotle famously posited six possible types of government, which correspond to the virtuous and deviant rule of three possible governors: the one, the few, and the many. ${ }^{109}$ The rule of one may consist in a "king" or a "tyrant." The few may constitute a virtuous "aristocracy" or a deviant "oligarchy," while the many may form a virtuous "constitutional government" or a deviant "democracy." 110 Virtue or deviance in turn depends upon the ruler's dedication to universal and distributive justice. Thus, for example, a monarch devoted to the common advantage, who bestows benefits based on virtuous desert, is a "king," while one who serves his own interests and practices cronyism is a "tyrant."111 A city-state may assume any of these forms, but the best government will always be one in which "the best men" are at the helm. ${ }^{112}$

Aristotle was practical enough to recognize, however, that virtuous statesmen will not always occupy government offices. He was therefore at some pains to describe the political structure best calculated to ameliorate the destructive tendencies of faction. In an insight that presaged James Madison by two millennia, ${ }^{113}$ Aristotle suggested that a "mixed regime," wherein class interests might offset one another, provides the best such protection. ${ }^{114}$ This is realized when both the "few" and the "many" share in the offices of power, manifesting some alloyed version of oligarchy and democracy. ${ }^{115}$ Aristotle called this form of government a "polity," and it again represents a kind of mean between potential extremes. ${ }^{116}$ Particularly in a community with a large middle class, Aristotle saw this division of authority as the scheme most likely to blunt the radical edges of factional avarice. ${ }^{117}$

107. Id.

108. Id. at III, 9, 1280a, 39-40; 1281a, 1-7.

109. Id. at III, 7.

110. Id.

111. See id. at III, 7-8.

112. Id. at III, 18.

113. See Peter Simpson, Aristotle's Regime of the Americans, in Aristotle's Politics Today 109, 109-27 (Lenn E. Goodman \& Robert B. Talisse eds., 2007).

114. See Politics, supra note 17 , at IV, 11.

115. See id. at IV, 8-9

116. See id. at IV, 9, 1294a, 30; IV, 11, 1295b, 1-5.

117. See id. at IV, 11, 1295b, 34-40; 1296a, 1-20. 
The Politics, then, clearly conceives the benefit of dividing political power among competing institutions, but this division is decidedly not an American style separation of powers. Aristotle's separation corresponds to class interests, not to the particular functions of any government office or authority, and is thus more akin to Federalist 10 than to Federalist 45.118 Although he recognized the existence of diverse political functions, including the judicial power, he did not argue for any particular institutional division along these lines. ${ }^{119}$ He therefore was not an early advocate of an independent judiciary. Nonetheless, in Aristotle we find a political science built in part around the principles of dividing, and thus tempering, political power. In this larger sense, he undoubtedly had a profound influence on the evolution of constitutional structure.

Several centuries later, the Greek historian Polybius would describe Roman efforts to put these principles into practice in his influential and enduring Histories. ${ }^{120}$ Indeed, Polybius went beyond Aristotle to argue that the best constitution is a mixture of monarchy, aristocracy, and the people. ${ }^{121}$ This happy circumstance he claimed for Rome:

The three kinds of government . . . were all found united in the commonwealth of Rome. And so even was the balance between them all, and so regular the administration that resulted from their union, that it was no easy thing, even for the Romans themselves, to determine with assurance, whether the entire state was to be esteemed an aristocracy, a democracy, or a monarchy. ${ }^{122}$

In the Consuls, Polybius saw elements of monarchy, and in the Senate the hallmarks of aristocracy. ${ }^{123}$ The People and their Tribunes, too, had such a "share . . . in the administration of affairs" that one might consider the state democratic. ${ }^{124}$ Though he undoubtedly idealized the Roman constitution, Polybius's description of its struc-

118. See id. at IV, 11, 1295b, 1-33.

119. See id. at VI, 1, 1317a, 3-9.

120. See Polybius, The General History of Polybius (Mr. Hampton trans., 3d. ed. 1773). For excellent treatments of Polybius and his thought, see Frank Walbank, Polybius (1972); Kurt von Fritz, The Mixed Government in Antiguity, supra note 4; Brian C. McGing, Polybius' Histories (Oxford Univ. Press 2010).

121. See Polybius, supra note 120.

122. Id. at VI, 2, 28.

123. See id. at VI, 2, 22.

124. Id. 
ture, and the particular benefits thus derived, became mandatory reading for future theorists up to and including John Adams. ${ }^{125}$

In particular, Polybius explored, as Aristotle had not, the specific powers that each part of the Roman regime exercised in government. ${ }^{126}$ The Consuls-the absolute military leaders in the field-also enjoyed substantial civil authority while in Rome: "For all other magistrates, the Tribunes alone excepted, are subject to them and bound to obey their commands." 127 They summoned the Senate and popular assemblies and carried out their decisions and decrees, and they could draw funds from the treasury to meet their personal needs. ${ }^{128}$ The Senate controlled all other spending, conducted criminal investigations, issued laws and decrees, and exercised extensive control in foreign policy matters. ${ }^{129}$ It also controlled the purse strings while the Consuls conducted war, and could terminate or continue a Consul's command on a yearly basis. ${ }^{130}$ Finally, the people exercised control of elections and the law courts, decided matters of war and peace, and had final approval over laws and peace treaties. ${ }^{131}$

There is fairly robust scholarly debate about the accuracy of Polybius's descriptions, ${ }^{132}$ but there is little doubt about his influence on future theorists. Again, like Aristotle, Polybius described a political structure divided by class, not by function. ${ }^{133}$ John Adams clearly recognized this distinction, and so expressly read these classical writers as a complement to the English Civil War theorists discussed below. ${ }^{134}$ With that said, Polybius did take particular care to describe the people's role in judicial affairs-hearing all capital and many lesser trials-and their representative Tribunes' power to veto Senate proceedings. ${ }^{135}$ While it is probably a stretch to claim that Adams found here an embryonic theory of judicial power, there is no doubt that Polybius's description of overlapping and di-

125. Gilbert Chinard, Polybius and the American Constitution, 1 J. Hist. IDEAS 38, 43-44 (1940).

126. See Polybius, supra note 120 , at $28-33$.

127. Id. at 23.

128. Id.

129. See id. at 24-25.

130. Id.

131. Id.

132. See generally McGing, supra note 120.

133. $I d$.

134. See John Adams, A Defence of the Constitutions of Government of the United States, V, I, 176 (1778) (Lawbook Exchange 2001) ("We may be convinced that the constitution of England . . . is a system far more perfect.") [hereinafter Adams].

135. See generally McGing, supra note 120. 
vided powers profoundly influenced the American's larger constitutional thought. ${ }^{136}$

During the Enlightenment, the Venetian constitution also took on a kind of mythical status in theoretical circles-due in no small part to Gasparo Contarini's 15th century De Magistratibus et Republica Venetorium. ${ }^{137}$ Translated into Italian, French, and English, this treatise became required reading for political theorists across Europe and in America. ${ }^{138}$ In it, Contarini repeatedly described the city's mixed regime in musical terms:

[It is] not unlike to a well-tuned dyapson in musicke, where the base is to the treble aptly proportioned, carrying with it the shew of a Monarchie, hath notwithstanding a correspondency with the popular government, and finally a middle fort of Magistrates being between them both interposed, doth grow (as it were) into a well concenting harmony of an excellent commonwealth. ${ }^{139}$

Like Polybius, to whom he often referred, Contarini's account is, in Elisabeth Gleason's words, "neither a faithful portrait nor a utopian tract, but a combination of the actual and the ideal, the descriptive and the prescriptive." 140 Perhaps most importantly, however, Contarini presented the checks and balances of Venice's mixed regime at least partly in terms of competing political ambitions. ${ }^{141}$

To this end, the Venetian constitution was structured to give as many people as possible a sense of ownership, power, and prestige. ${ }^{142}$ Contarini thus claimed that each part of government- the monarchical Doge, the aristocratic Senate, and the democratic Great Council-could make a certain "shew" of political authority. ${ }^{143}$ In this way, not only did competing offices hold each other in

136. See AdAms, supra note 134, at V, I, 171-76 (recounting in depth Polybius's account of the mixed Roman regime).

137. See Gasparo Contarini, The Commonwealth and the GovernMENT OF Venice (Lewes Lewkenor trans., Edmund Matter 1599) (1543). On Contarini's biography, see Elisabeth G. Gleason, Gasparo Contarini: Venice, Rome, AND ReForm (1993). For an excellent overview, see William J. Bouwsma, Venice and the Defense of Republican Liberty (1968); Elisabeth G. Gleason, Reading Between the Lines of Gasparo Contarini's Treatise on the Venetian State, 15 Hist. Reflections, Spring 1988, at 251, 252.

138. See Gleason, supra note 137, at 251.

139. CONTARINI, supra note 137, at 36.

140. GleAson, supra note 137, at 113.

141. See Gordon, supra note 93 , at 221.

142. See Contarini, supra note 137 , at 33 ("[T] he offices are so divided among the citizens, that ... every family $\&$ kindred may be pertaker of the publicke honors and offices.").

143. See id. at 35 ("Whereby you may plainly perceive, that in this manner of our government there is mingled with a popular shew, the forme of a nobler rule, 
check, but enough citizens felt invested in the state to provide a sense of legitimacy and forestall large scale unrest. ${ }^{144}$ Thus, Contarini was more pragmatic and overtly concerned with practical politics than his Greek predecessors. As Scott Gordon observes, he was "not anxious to press the institutions of the Venetian state into the traditional Aristotelian taxonomy. His analysis is carried out in terms of a different conception-the notion of checks and balances." 145 And it was in part this focus that allowed English theorists to begin to see "mixed government" as "divided government": that is, specifically to contemplate a division of institutional functions rather than a structured representation of class interests.

2. The English Civil War - The English Civil War and its aftermath produced the ideas that became the direct antecedents of the American doctrine of separation of powers. ${ }^{146}$ It was during and after the contest between the Stuart King Charles I and Parliament that English theorists began to clarify the distinctions between executive and legislative power, and began to carve judicial authority away from both-all against the backdrop of emerging popular sovereignty theories. Indeed, it is difficult to overstate the importance of this period in the intellectual development of Anglo-American constitutionalism. ${ }^{147}$ Before delving into these ideas in detail,

fed with such temperature that the fame doth not exceed nor go beyond the mean \& manner of popular authority.").

144. See id. at 32-33 ("[T]hrough too much greatness of power [the few] might become disturbers or oppressors of the commonwealth: and on the other side, [if the many] find themselfes voide and hopelesse of honour and government, might grow into a dislike and hatred of the same.").

145. Gordon, supra note 93, at 161. For representative passages, see ConTARINI, supra note 137 , at 33-35.

146. For an excellent overview of this period, see Mark KishlansKy, A Monarchy Transformed: Britain 1603-1714 (1996). See also S. R. Gardiner, The History of the Great Civil War vols. 1-4 (1883); Blair Worden, The English Civil Wars: 1640-1660 (2009); G.E. Aylmer, Rebellion or Revolution? England 1640-60 (1986); J.P. Kenyon, The Civil Wars of England (1988); The Nature of the English Revolution (J.S. Morrill ed., 1993); George Burton Adams, Constitutional History of England (1921); F.W. Maitland, The Constitutional History of England (1908); Goldwin Smith, A Constitutional and Legal History of England (1990); G.P Gooch, History of English Democratic Ideas in the Seventeenth Century (1927); Margaret A. Judson, The Crisis of the Constitution: An EsSay in Constitutional and Political Thought in England 1603-1645 (1949); T.C. Pease, The Leveller Movement: A Study in the History and Political Theory of the English Great Civil War (1916); Edward Jenks, The Constitutional Experiment of the Commonwealth 1649-1660 (1890); David Hume, The History of England, vols. 5 \& 6 (William B. Todd ed., Liberty Fund 1983) (1761).

147. KishlansKy, supra note 146 , at 4-5. Edmund Morgan vividly recounts the importance of this legacy to the American model. See generally Morgan, 
however, it is worth very briefly summarizing the events that we have come to call the English Civil War.

Charles I ascended to the throne in 1625 and was quickly at odds with Parliament. ${ }^{148}$ Steeped in the doctrine of divine right and royal prerogative, Charles chafed at the assembly's control over the treasury, and in 1629 he dissolved the body altogether. ${ }^{149}$ For the next decade, he resorted to unorthodox and unpopular taxation schemes during the period known as the Eleven Year Tyranny. ${ }^{150}$ By 1640, low on funds and facing a religious uprising in Scotland, Charles reconvened Parliament, but dismissed it just three months later when leadership criticized his policies. ${ }^{151}$ With the aptly named "Short" Parliament dissolved, military matters worsened in the north, and a desperate Charles was forced to call a new assembly, which would sit for the next twenty years. ${ }^{152}$

This "Long" Parliament immediately introduced reform measures, including a provision for regular assembly and a prohibition on the King's power to dissolve the body without its consent. ${ }^{153}$ Notably, it also abolished the King's prerogative courts-including the infamous Star Chamber-citing arbitrary abuses of power. ${ }^{154}$ Charles reluctantly agreed to these changes, but when Parliament also forced him to sign an act of attainder for the execution of the Earl of Strafford-his close adviser and confidant - the King began to prepare for war. ${ }^{155}$ In 1642, Charles marched on Westminster in a failed attempt to arrest five leading members. ${ }^{156} \mathrm{He}$ then withdrew to Oxford and the period of official civil war began. ${ }^{157}$

supra note 16 , at 94-120. There is, however, at least one fairly recent account that grossly underestimates the English Civil War's importance in the shift from the "mixed regime" to modern separation of powers theory. See Steven G. Calabresi, Mark E. Berghausen \& Skylar Albertson, The Rise and Fall of the Separation of Powers, 106 Nw. U. L. REv. 527, 531-35 (2012) (attributing shift from "mixed regime" to separation of powers theory primarily to "Enlightenment" and American Revolution).

148. 5 Hume, supra note 146 , at 165-66.

149. Id. at 217.

150. Goldwin Smith, A Constitutional and Legal History of EnGLAND 322-23 (1990).

151. Matthew A. Pauley, Athens, Rome, and England: America's Constitutional Heritage 169-70 (2011).

152. Sмітн, supra note 150 , at $322-28$.

153. Triennial Act, 16 Cha. 1 c. 1 (1641), https://bit.ly/3dgccYA [https:// perma.cc/94VJ-L9BV].

154. Habeas Corpus Act of 1640, 16 Car. 1 c. 10 (1640).

155. 5 Hume, supra note 146, at 325; SMith, supra note 150, at 327-29.

156. Sмiтh, supra note 150 , at 330.

157. Id. at $330-31$. 
The next few years saw the ancient houses divided into Royalists and Parliamentarians. ${ }^{158}$ In the early going, Charles had some military success, but with Scotland's aid, and under the emerging leadership of a cavalryman named Oliver Cromwell, Parliament eventually gained the upper hand. ${ }^{159}$ Initially, the victorious Parliamentarians hoped to negotiate Charles's return to a limited role in government. ${ }^{160}$ But after a series of intrigues and betrayals, Cromwell's army purged the assembly of Royalist sympathizers, and the remaining "Rump" Parliament tried and executed Charles for treason in January of $1649 .{ }^{161}$

Following his father's death, Charles II joined Scottish forces in an attempt to challenge Cromwell's army. ${ }^{162}$ With this effort turned back, however, he went into exile in France. ${ }^{163}$ After the Royalists' defeat, power passed into the hands of Parliament, and Cromwell assumed control of the army under the title Lord Protector. ${ }^{164}$ This "Protectorate" lasted until Cromwell's death in $1658 .{ }^{165}$ Cromwell's son, Richard, attempted to assume his father's title, but without military support he quickly faltered. ${ }^{166}$ Parliament then offered Charles II a conditional return to the throne. ${ }^{167}$ In 1660 , Charles II promised to protect religious liberty and property rights, and the period known as the Restoration began. ${ }^{168}$

Charles II presided over an uneasy resettlement period, as he became increasingly supportive of Catholicism, and so more at odds with Parliament. ${ }^{169}$ Upon Charles II's death in 1684, the crown passed to his openly Catholic brother James II, which would precipitate the Glorious Revolution and William and Mary's ascension in 1688. ${ }^{170}$ In many English and American minds, the end of the Stuart reign finally restored order to the ancient constitution. ${ }^{171}$ And, again, it is no exaggeration to say that these events ushered in an

158. Id. at 331-34.

159. Id. at $332-34$.

160. 5 Hume, supra note 146 , at 505 .

161. Id. at $513,532-40$.

162. KishlansKy, supra note 146 , at 386.

163. Id. at 387.

164. Sмiтh, supra note 150 , at 343.

165. See 6 Hume, supra note 146, at 106-07.

166. Id. at $112-15$.

167. Id. at $138-40$.

168. $I d$.

169. See Nathan C. Harkey, The Political Consequences of King Charles II's Catholic Sympathies in Restoration England, 6 Tenor OF OUR TIMEs 58, 60-62 (2017).

170. SMith, supra note 150 , at 365-68.

171. Gordon S. Wood, The Creation of the American Republic: 1776-1787, 30-31 (2d ed. 1998) [hereinafter WoOd, Creation]. 
ideological revolution in Western thought about constitutionalism and the separation of powers. ${ }^{172}$

Very roughly speaking, this thought developed in three stages. Much of the early dispute between Charles and Parliament appealed to the ancient constitution and the traditions of a mixed regime. ${ }^{173}$ Then, with a splintered Parliament assuming ever-greater power, discussion turned towards restraining both the King and the assembly, and saw the evolution of a true "separation of powers" doctrine, with more clearly defined executive and legislative functions. ${ }^{174}$ Finally, during the Protectorate and Restoration, critical reflection on the abuses of both the King's prerogative courts and parliamentary acts of attainder inspired more developed thought about a distinct judicial power, and the need for a "balanced constitution" that might better protect the emerging notion of a popular sovereign. ${ }^{175}$ Nearly a century later, these ideas would inform Montesquieu's famous account of the modern tripartite separation.

Any effort to begin exploring this intellectual history drops us into the middle of an ongoing conversation, but, for present purposes, there is probably no better place to start than with Charles's initial responses to the Long Parliament's grievances. In June of 1642, parliamentary leaders published The Nineteen Propositions, which laid out the assembly's demands of the King. ${ }^{176}$ Many of these required Charles to reject Catholicism at home and abroad, and to educate future generations as Protestants. ${ }^{177}$ Others, however, directly challenged aspects of the King's traditional prerogative-by requiring parliamentary approval for royal pardons, appointing judges, military leaders, and royal councilors; and by prohibiting the King from removing judges during "good behavior."178 Significantly, the Propositions also demanded the King's assent to the recent Militia Ordinance, which would put the bulk of the nation's military forces under Parliament's command. ${ }^{179}$

172. See generally R. C. Latham, English Revolutionary Thought, 1640-1660, 30 History 38 (1945) (recounting blossoming of separation theories).

173. VILE, supra note 93 , at $44-47$.

174. Id. at $47-49$.

175. Id. at $49-50$.

176. Nineteen Propositions made by both Houses of Parliament, to the Kings most excellent Majestie (1642), reprinted in 1 The Struggle for Sovereignty: Seventeenth-Century English Political Tracts 145-154 (Joyce Lee Malcolm ed., Liberty Fund 1990) [hereinafter STRUGGLE FOR SOVEREIGNTY].

177. Id. §§ IV, V, VI, VII, VIII, XVII.

178. Id. §§ I, II, III, XII, XIV, XV.

179. Id. § IX. 
Charles promptly offered his Answer to the Nineteen Propositions, which has in time become more famous than the propositions themselves. ${ }^{180}$ Authored by two of the King's more moderate advisers, the Answer began by accusing Parliament of "undermining the very foundations" of the ancient law: ${ }^{181}$

[A] new Power hath been assumed to interpret and declare Laws without Us, by extemporary Votes, without any case judicially before either house, (which is in effect the same thing as to make Laws without us) Orders and Ordinances made only by both houses (tending to a pure Arbitrary power) were pressed upon the people, as Laws, and their obedience required to them. ${ }^{182}$

The Answer went onto describe Aristotle's three forms of government, each burdened with potential "inconveniences."183 It then argued that Parliament threatened to destroy the venerable English mixed regime, and so to reduce the government to deviance and corruption. $^{184}$

Significantly, however, the King conceded that his was a coordinate - and thus in some sense an equal-estate of the ancient English constitution. ${ }^{185}$ This was a momentous concession, as it seemed to align with the more liberal constitutional ideas of contemporary theorists like Charles Herle and Philip Hunton. Herle, a Parliamentarian clergyman, used the same language in his public debate with divine right theorist and royal chaplain, Henry Ferne: "[In England] the Monarchy, or the highest power is itself compounded of three coordinate Estates, a King, and two Houses of Parliament."186 And Hunton-whose A Treatise of Monarchie tried to claim a theoretical middle ground-likewise argued that the mixed constitution put "into [Parliament's] hands a power to meddle in acts of the highest function of government; a power not depending on his will, but radically [its] own."187 In signing on to

180. 1 Struggle for Sovereignty, supra note 176, at 146.

181. His Majesties Answer to the Nineteen Propositions of Both Houses of Parliament, reprinted in 1 Struggle for Sovereignty (1642), supra note 176, at 154-78 [hereinafter ANSwER]. The Answer was written by Sir John Colepepper and Viscount Lucius Cary, who had worked with Parliament the previous year. 1 Struggle fOr SovereignTy, supra note 176, at 146.

182. Answer, supra note 181 , at 155.

183. Id. at $167-68$.

184. Id.

185. Id.

186. Charles Herle, A Fuller Answer to a Treatise Written by DOCTOR FERne 2 (London, 1642), https://bit.ly/3nFep4L [https://perma.cc/XUR9S2DC]. (1643)

187. Philip Hunton, A Treatise of Monarchie, Pt. II, Chap. 3, Sec. 1 
something like this position, then, Charles, or at least his advisors, seemed willing to concede a coordinate status with the other estates in order to preserve the monarchy against more radical parliamentary voices.

The Answer is remarkable, too, in its Polybian effort to delineate the particular powers held in each estate. Entrusted to the King were:

[T] he Power of Treaties of War and Peace, of making Peers, of chusing Officers and Councellors for State, Judges for Law, Commanders for Forts and Castles, Commissions for raising men for War abroad, or to prevent or provide against Invasions or Insurrections at home, benefit of Confiscations, power of pardoning, and some more of the like ... ${ }^{188}$

The House of Commons provided a popular check, so that "the Prince may not make use of this high and perpetuall power to the hurt of those for whose good he hath it." ${ }^{189}$ Commons was, however, "never intended for any share in Government, or the chusing of them that shall govern," but rather was "solely intrusted with the first Propositions concerning the Levies of Moneys, and the Impeaching of those who . . . have violated the law."190 The House of Lords, in turn enjoyed something like the judicial authority, being "trusted with a Judicatory power, [as] an excellent Screen and Bank between the Prince and the People . . . by just Judgements to preserve that Law, which ought to be the Rule of every one of the three [estates]." 191

The Answer insightfully summarized this structure as giving Parliament the "power of punishing," while reserving to the King the "power of preferring." 192 This, of course, goes beyond the "mixed regime" and begins to suggest a true "separation of powers" theory, with separate authority divided among separate institutions. "[T] he incroaching of one of these Estates upon the power of the other," the Answer continued, "is unhappie in the effects both to them and all the rest." 193 Thus, to accept the Propositions would be to abdicate the King's constitutional duty and abandon the People to the whims of an absolute and arbitrary Parliament:

188. ANSwer, supra note 181, at 168.

189. Id.

190. Id. at $168-69$.

191. Id. at 169.

192. Id . at 170. Thus, the King may appoint, reward, or pardon; while Parliament punishes those who abuse the public trust. Id.

193. Id. 
[W]ithout the power which is now asked of Us, we shall not be able to discharge that Trust which is the end of Monarchie, since this would be a totall Subversion of the Fundamentall Laws, and that excellent Constitution of this Kingdom, which hath made this Nation so many yeers both famous and happie to a great degree of Envie. ${ }^{194}$

Whether Charles himself truly accepted this accounting, particularly as it might limit his own authority, is perhaps an open question. ${ }^{195}$ There is little doubt, however, that the Answer accurately foresaw an unwelcome consolidation of power in Parliament.

In the years following Charles's surrender, concerns about parliamentary supremacy began to emerge even from within the body itself. As M. J. C. Vile observes:

The divisions within the parliamentary camp were deep and serious. Presbyterians, Independents, and Levellers, were deeply hostile to each other, and other sectarian divisions loomed ominously. The use of Parliament by one group of its supporters to threaten other groups had shown to men who had previously seen only the royal power as a danger, that a parliament could be as tyrannical as a king. ${ }^{196}$

Perhaps the most radical ideas on this point came from the Levellers, a populist movement dedicated to extended suffrage, the rule of law, and equal natural rights. Moreover, they presented their ideas in the novel form of a written constitution. In three successive constitutional proposals, each entitled The Agreement of the People, the Levellers and their leader John Lilburn demanded restraints on Parliament's authority, including in the exercise of what we now think of as judicial power. ${ }^{197}$

194. Id. at 169 .

195. Struggle For Sovereignty, supra note 176, at 146-47 (Editor's note).

196. VILE, supra note 93, at 48.

197. An Agreement of the People for a Firme and Present Peace (1647) [hereinafter Agreement I]; An Agreement of the People proposed as A Future Rule for Government (January, 1649) [hereinafter Agreement II]; An Agreement of the People tendered as a Peace Offering to this Distressed Nation (May, 1649) [hereinafter Agreement III] reprinted in AN ANthology of Leveller Tracts: Agreements of the People, Petitions, Remonstrances, and Declarations (1646-1659) (Online Library of Liberty, 2014), https://bit.ly/3mVhVXs [https://perma.cc/L67Y-JNPH] [hereinafter LEVELLER TRACTS]. The first Agreement was submitted for parliamentary approval in October, 1647. The Leveller "Council of the Army" submitted the second in January, 1649; and John Lilburn prepared the third in May, 1649, while imprisoned for sedition in the Tower of London. Elizabeth O. Hughes, The Levellers in England and the Adoption of Their Principles in the United States 40 n.1 (May 27, 1921) (unpublished master's thesis, University of Southern California) (available at https://bit.ly/2Uxhd6O [https://perma.cc/YF3X-4PBL]). 
The Agreements enumerated an evolving list of powers forbidden to Parliament. By the second Agreement, these included, "[t]hat the Representatives intermeddle not with the execution of the Lawes, nor give judgment upon any man's person or estate where no Law hath been before provided"; 198 and by the third, "[t]hat it shall not be in their power to continue or make a law, for any other way of Judgments, or Conviction of life, limb, liberty or estate, but onely by twelve sworn men of the Neighborhood."199 By 1653, the Levellers were even clearer in their criticisms of absolute power in either King or Parliament: "Prerogative and Supremacy with that of unknown, unlimited Parliament Priviledge, [are] the very Mothes and Caterpillars of the Fundamental Laws and Liberties of the Free people of England." ${ }^{200}$ Thus, they continued to demand that both institutions surrender, among other things, elements of judicial authority. In particular, they asserted: "[t]hat Parliaments are not Executioners of the Law"; that "the whole execution thereof be referred to particular Courts of Justice"; and that, "[t]he Juries of England are the Judges of matter of Law, as well as matter of Fact." 201

Notably, the Levellers rooted their structural demands in fairly radical ideas about popular sovereignty - a conception that would inform James Wilson's American vision in important ways. ${ }^{202}$ For example, the latter two Agreements appealed to the People's authority in calling for a reapportionment of parliamentary boroughs, with representation tied directly to population. ${ }^{203}$ It was this very circumstance which Wilson would identify as "the rotten part of the [English] Constitution" in his push for an apportioned American Senate: "[A]ll authority [is] derived from the people, [thus] equal numbers of people ought to have an equal number of representatives." ${ }^{04}$ The Levellers also defended the right of revolution when the King (as agent) ceased to serve the interests of the people (as

198. Agreement II, supra note 197 , at art. VII, $\S 6$.

199. Agreement III, supra note 197, at art. XXV.

200. The Fundamental Lawes and Liberties of England (1653) art. III, reprinted in LEVELLER TRACTS, supra note 197.

201. Id. at art. III, $\S \S 7,8,11$ (emphasis added).

202. For an excellent discussion of the Levellers' ideas on popular sovereignty and written constitutionalism, and their echoes in America, see Michael Kent Curtis, In Pursuit of Liberty: The Levellers and the American Bill of Rights, 8 Const. Comment. 359, 367-68 (1991); compare with Morgan, supra note 16, at 75-85.

203. Agreement I, supra note 197, at art. II; Agreement II, supra note 197, at art. I-VII.

204. See James Madison, Notes of Debates in the Federal ConvenTION OF 1787, 97, 126, 208 (W.W. Norton \& Co. 1987) (1840) (recording remarks of James Wilson) [hereinafter Madison's Notes]. 
sovereign), the same Lockean principle Wilson would assert in his Lectures on Law in Philadelphia. ${ }^{205}$ Finally, the Levellers actively supported jury nullification, even if they did not make explicit its connection to the right of revolution, as would Wilson in his account of the American jury. ${ }^{206}$ The Levellers, then, provided the American founders with the model of a written constitution implementing popular sovereignty through the separation of delegated prerogatives.

Though far removed from the Leveller's populism, Royalist sympathizers, too, began to recognize the importance of a separate judicial authority charged with identifying the "knowne law of the land," to act as settlor of disputes between the King and Parliament. ${ }^{207}$ From exile in France, Sir Charles Dallison penned The Royalist's Defence, in which he hoped to "vindicate" Charles's fight against parliamentary efforts to "reduce[ ] the people to an unparallel'd slavery."208 From its opening sentences, Dallison's Defence made the case for an independent judiciary, in language worth quoting at length:

In every Common-wealth where the tyranny of an Arbitrary power prevailes not, some known persons are assigned; unto whom, for matters of law, both the Governours, and the Persons governed, do submit: For example, where a King hath the Soveraignty, if it be likewise in his power to judge the Law, his authority is Arbitrary: He may then take the life, or confiscate the estate of whom he pleaseth, and for what cause he thinks fit.

And the same it is, when the soveraigne power is in severall persons, whatever their number be, and however composed, if they have also authority to judge the Law by which they govern, the rest of the People are inslaved to their will.

But herein the Subjects of England are a most happy people; By the constitutions of this Realm, our King hath inherently in His Person the soveraigne power of government, but He hath not authority to judge the Law. The Judges of the Realme declare by what law the King governs, and so both King and people are regulated by a known law. ${ }^{209}$

205. Curtis, supra note 202, at 367.

206. Fundamental Lawes and Liberties, supra note 200, at art. III, § 11. On Wilson and juries, see discussion infra II.A.

207. Charles Dallison, The Royalist's Defence Vindicating the King's Proceedings in the Late Warre Made Against Him (1648), https:// bit.ly/2GTj4zg [https://perma.cc/JQ5F-GM65] [hereinafter DALLISON]. For a brief overview of Dallison's views on the rule of law, see John Sanderson, Charles Dallison and the Rule of Law, 11 J. Legal Hist. 239 (1990).

208. Dallison, supra note 207, at Preface.

209. Id. at Preface. 
Dallison went on to offer perhaps the first perspicuous effort to root the rule of law in a truly tripartite separation of powers doctrine. ${ }^{210} \mathrm{He}$ recognized the deep incompatibility between traditional conceptions of absolute sovereign authority and a "King ... regulated by a known law" - and he hoped to provide a structural resolution. ${ }^{211}$ And, although he did not conceive of dividing or delegating sovereignty itself, his ideas on the authority of a constituted judiciary-in the best Bodinian tradition-would provide an important bridge to the American model. ${ }^{212}$

To be sure, Dallison believed the Crown retained sole authority both to appoint the "Judges of the Realme" and to define their jurisdictions - the King's Bench, the Court of Common Pleas, the Barons of the Exchequer, and so on-and certainly he envisioned these institutions working primarily to check parliamentary overreach. ${ }^{213}$ But, once appointed, the judiciary enjoyed the final say on the law's meaning and effect, even as binding on the King. ${ }^{214}$ Indeed, Dallison plainly stated the case for final judicial review of legislation enacted by the King-in-Parliament:

[I]n case the King, and the two Houses make an Act of Parliament ... when that Act is passed ... an appeale lieth ... unto the Judges, who have power to determine whether that Statute be binding or void, and therefore clear and manifest it is, that in matters of Law the last and finall sentence, is the [J]udges of the Realme. ${ }^{215}$

Thus, even if judicial appointment remained squarely within the King's prerogative, within their jurisdictional bounds these judges enjoyed the final, and independent, authority to declare the law of the land. ${ }^{216}$

210. Id. at Preface (the "Soveraigne power of government, power to make Lawes, and powers to judge the Law, are three severall things; and ... ought to be in three severall hands."); accord VILE, supra note 93, at 50-52; Sanderson, supra note 207 , at 240 .

211. Dallison, supra note 207, at Preface.

212. Recall Bodin's account of the "bilateral obligations" that exist between a King and his "constituted magistrates." See discussion supra note 62.

213. Dallison, supra note 207 , at chs. V, VI $(49,64)$.

214. Id., ch. V, at (59).

215. $I d$.

216. Dallison makes the same argument in a number of ways, to wit: "This Nation is governed by a known Law, that Law acknowledgeth the King to be our onely Supream Governour, gives power to the King, with the assent of the two Houses, and no other, to alter that Law and to make new Lawes, And to the Judges of the Realme it ascribes the power to finally declare the Law . ..." DALLISON, supra note 207, at 60. 
Most commentators treat this English term of art-the "law of the land"-as the antecedent of our Due Process Clause, which likewise protects individuals from arbitrary government intrusion. ${ }^{217}$ Dallison dated his own definition back to William the Conqueror, to whom "the people of this Nation submitted" upon the promise of "Govern[ance] by known Laws": 218

[B]y the Constitutions of the Realme (as now is settled) the Law of England consists in these three particulars: 1. Generall Customes ... [which] are generally Law throughout the Kingdome, therefore called the Common Law. 2. Particular Customes... . [which] by antient, constant, and frequent use, is become Law [in a particular place] although not generally throughout the Kingdome; [and] (3) Acts of Parliament made by the King with the assent of the two Houses . . . . 219

With these transcendent legal traditions in place, neither Parliament nor King had "an absolute or an unlimited power over the people . . .".220 Both exercised authority only through legal processes, and when either estate did "such things as the rules of that Law cannot warrant," it was incumbent on judges to declare the action void. ${ }^{221}$

Undoubtedly, the Royalist Dallison intended his Defence primarily as a broadside against Parliament and its unilateral conduct during the Civil War. All of his examples of departures from the known law were statutes denying or ignoring the King's negative voice, and foremost among these was the Militia Act. ${ }^{222}$ But ultimately, by framing his case as a defense of the People's rights, Dallison also constructed an account that would make the separation of powers a perfect complement to emerging popular sovereignty theories. ${ }^{223}$ His carefully theorized judicial defenses of the King's sovereign rights would, in American hands, become an institutional judiciary charged with protecting the sovereign People against the potential avarice of their legislative and executive agents. Indeed,

217. See, e.g., Randy E. Barnett \& Evan D. Bernick, No Arbitrary Power: An Originalist Theory of the Due Process Clause, 60 WM. \& MARY L. Rev. 1599, 1608, 1613-14 (2019); Philip Hamburger, Law and Judicial Duty 179-218 (2009); Raoul Berger, "Law of the Land" Reconsidered, 74 Nw. U. L. Rev. 1, 1 (1979).

218. DAllison, supra note 207, at 3.

219. Id. at 3-4.

220. Id. at $39-40$.

221. Id. at 40. Accord Hamburger, supra note 217, at 179-218.

222. DAllison, supra note 207, at 90-97.

223. Id. at Preface (providing a summary of Chapter V) ("[I]f the King or the two Houses have [the power to Judge the Law], the known Law is destroyed, and the people inslaved."). 
in Dallison we see the beginnings of a theory that might marry the separation of powers to popular sovereignty in support of the rule of law.

During the transition from Protectorate to Restoration, clergyman George Lawson revisited some of these ideas from a Parliamentarian perspective, and so provided an intellectual link between the early Civil War theorists and John Locke. ${ }^{224}$ A Cambridge educated Rector, Lawson's intellect earned the admiration of several notable contemporaries, including the Puritan theologian Richard Baxter, who remembered him as "the ablest ... man of any I know in England . . . above all by his great skill in politics . . ."225 In particular, two books published around the time of Cromwell's death-An Examination of the Political Part of Mr. Hobbes, His Leviathan, and Politica Sacra et Civilis - made their way into many private libraries, including Locke's. ${ }^{226}$ As the titles suggest, Lawson took up his political pen primarily in opposition to Hobbesian moral egoism and its deleterious effects on young university students. ${ }^{227}$ Along the way, however, he developed a sophisticated and original account of sovereignty and popular reform. ${ }^{228} \mathrm{He}$ also divided the traditional executive power into two separate political functions, one of which rightly belonged with the judiciary. ${ }^{229}$

In matters "temporal and humane," Lawson began, there are "two acts of majesty: [. . ] legislation, [and the] execution of laws made ...."230 The latter, "executive," power also has two features: (1) "the right of making officers" and (2) "the administration of justice." 231 The second executive authority, "whereby justice is administered," Lawson identified as "the power of jurisdiction," which he again divided in two: "Under this head I comprehend, not only the power of those acts of judgement, more strictly so called, as convention, discussion, decision of the cause upon [the] evidence of

224. See A.H. Maclean, George Lawson and John Locke, 9 CAMBridge Hist. J. 69, 69-70 (1947); accord Julian Franklin, John LOCKE AND THE THEORY OF SOVEREIGNTY 87-90 (Cambridge 1978).

225. Maclean, supra note 224, at 72.

226. Id. at 75. There is some dispute over the sequence of these books' creation. Julian Franklin contends the Politica was written before the Examination, but not published until three years later. FrankLIN, supra note 224, at 53, 87. Conal Condren is less certain about the date of the Politica's completion. Conal ConDren, George Lawson's Politica and the English Revolution 34 (1989).

227. Maclean, supra note 224, at 72 .

228. Franklin, supra note 224, at 53-86.

229. VILE, supra note 93, at 60-61.

230. George Lawson, Politica Sacra et Civilis 51 (Conal Condren ed., Cambridge 1992) (1660) [hereinafter Politica].

231. Id. at 52 . 
the merit or demerit, but the execution."232 Finally, it is the former "acts of judgement" which Lawson would carve away from the King as an independent power: "From all this it is evident, that all Jura Majestatis may be reduced to the legislative, judicial, and executive power, if we understand judicial and executive in a larger sense, then they are commonly taken." ${ }^{233}$ And in the end, even the "coactive" executive authority-that of "Execution by the Sword"can act only in coordination with the separate and independent powers of legislation and judgment. ${ }^{234}$ Thus, "there is no power to punish the good and protect the bad. For the Sword must execute according to Judgement, and that must pass according to Laws ...."235

Further, by reading the Levellers and Dallison together, Lawson hinted at a deeper insight into the separation of powers as a structural realization of popular sovereignty. In developing his modest account of popular resistance and reform, Lawson invoked the longstanding distinction between "real" and "personal" sovereignty. ${ }^{236}$ Here he reached back to Besoldus and other postBodinians, who had used these property law concepts to clarify their own claims about popular sovereignty. ${ }^{237}$ Like "real" property, "real" sovereignty was unmovable and permanent, whereas "personal" sovereignty might move between various temporary locations. $^{238}$ In Lawson's formulation, real sovereignty was "the power to constitute, abolish, alter, [or] reform forms of government," while personal sovereignty concerned "foreign affairs, peace, war, treaties, embassies; and the regulation of religion and human law." "239

For Lawson, the real-personal distinction aligned with several others-the "community" versus the "polity"; the "citizen" versus the "subject"; and the "ecclesiastical" versus the "civil."240 In each case, real or permanent sovereignty is superior. Thus, Lawson asserted, "Real [sovereignty] is in the community, and is greater than personal, which is the power of a commonwealth already consti-

232. Id. at 53-54 (emphasis supplied).

233. $I d$. at 54.

234. George Lawson, An Examination of Mr. Hobbes, His Leviathan, 7-8 (1657) [hereinafter ExAMINATION].

235. Id. at 8.

236. Politica, supra note 230 , at 49 . Lawson frequently uses the term "majesty" in place of "sovereignty"; here arguing, "As there is real, so there is personal majesty so called ...." Id. (emphasis supplied).

237. FrankLIN, supra note 224, at 67-68; see also discussion supra note 48.

238. FrankLin, supra note 224, at 67-68.

239. Politica, supra note 230, at 47.

240. Id. at $46-54$. 
tuted."241 Likewise, the "citizen" is repository of those elements of real sovereignty, which the "subject" cannot cede to the government; and the Church reserves its divine authority even in temporarily submitting to secular authorities. ${ }^{242}$ And, perhaps most importantly, those temporarily vested with personal sovereignty "may, and many times do, forfeit [it] to God, and in some cases forfeit it to the community or the people." 243

Indeed, in this way the concept of real sovereignty underwrote Lawson's theory of constitutional dissolution, by which sovereignty reverts to the people when the government abdicates its duties as legal agent:

As this real majesty is a power to model a state, so it is always inherent and can never be separated; insomuch, that when a form of government is dissolved ... the power of the sovereign doth devolve unto them by the law of nature, or rather it was always in the people. As this community hath the power of constitution, so it hath of dissolution, when there shall be just and necessary cause. ${ }^{244}$

This theory, precursor to Locke's "revolution principle," was the cornerstone of Lawson's defense of Parliament's actions during the Civil War. ${ }^{245}$ When Charles violated the known law and broke away from Parliament in 1642, "the constitution was dissolved, and the personal majesty forfeited." 246 The King's illegality left Parliament with no recourse but to allow the people to "alter the former government or model a new one." 247 At that moment, Parliament ceased to be a sovereign body and became instead a representative convention of community will as manifested in the forty county courts. ${ }^{248}$

On the eve of the Restoration, then, all the conceptual pieces existed to lodge the revolutionary prerogative in an institutionally independent judiciary. Dallison, the Royalist, and Lawson, the Parliamentarian, approached the aftermath of the Civil War from opposite sides, yet each recognized the need for a distinct judicial

241. Id. at 47.

242. See Condren, supra note 226, at 104-05.

243. Politica, supra note 230 , at 49 . Lawson is clear here that "the people is not the plebs ... but the whole community as a community." Id.

244. Id. at $47-48$.

245. Franklin, supra note 37 , at 78-79, 96-100. Condren, again, is less certain about Lawson's direct influence on Locke. Condren, supra note 226, at 107-11. On Locke's revolution principle, see discussion supra Section I.A.4.

246. FrANKLIN, supra note 37, at 79.

247. $I d$.

248. See id. at 74; accord Morgan, supra note 16, at 88. 
authority-neither wholly legislative nor executive-and both would have seen this institutionalized in a quasi-independent body. Both men claimed that the known law of the land-the common law and constitutional tradition-bound the sovereign authority even of the King-in-Parliament, and Dallison argued that the judges enjoyed final authority to identify that law. Lawson went on to argue that, upon a substantial constitutional breach, sovereignty reverted automatically to the whole community of citizens. Taken together, then, we find a popular sovereign of Marsilian and Bodinian descent, a government delegated temporary sovereign authority contingent upon its respect for constitutional tradition, and a potential judicial institution empowered to enforce that contingency in the name of the people.

In truth, however, neither man put these pieces together in an integrated whole. Dallison, though he saw judicial enforcement of constitutional traditions as the People's safeguard, never asserted anything like a coherent theory of popular sovereignty; and he imagined a judiciary still under the umbrella of executive authority. While Lawson developed an account of popular sovereignty, he did not envision judges identifying violations of fundamental or natural law, leaving such matters to private judgment and to God. ${ }^{249}$ The same was true of John Locke, who adopted much of Lawson's theory of government and the separation of powers. ${ }^{250}$ It was thus left to a Frenchman to revitalize ideas about independent judicial power, and to popularize the constitutional structure by which the Americans would come to institutionalize revolution as a legal principle.

3. Montesquieu and Blackstone-Charles-Louis de Secondat, Baron de la Brede et de Montesquieu, was a French judge and political philosopher whose ambitious treatise The Spirit of the Laws was widely disseminated in the American colonies. ${ }^{251}$ While the work's central thesis is a kind of legal relativism, in which a nation's laws reflect the particular "spirit" of its people, Montesquieu also popularized the tripartite separation of political authority. He was not the first to delineate distinct legislative, executive and judicial powers-Clement Walker and Marchmont Nedham, among those others discussed above, applied these labels nearly a century ear-

249. See Examination, supra note 234, at 123 ("Even of Laws [the individual . . . must within himself . . . enquire, examine, and determine . . . Yet this must not be done to ... raise sedition, or rebel; but we may complain to God, and by our humble prayers seek redress.").

250. See discussion of Locke supra I.A.4.

251. See generally Matthew P. Bergman, Montesquieu's Theory of Government and the Framing of the American Constitution, 18 PePP. L. REv. 1 (1990). 
lier-but it was largely through Montesquieu that this framework entered American discourse..$^{252}$

Certainly, his particular vision of judicial power is far more limited in both substance and scope than what would emerge in the United States, but the structural separation of a discrete judicial function is clear. Importantly, Montesquieu would vest this limited judicial authority primarily in juries ${ }^{253}$ - not in professional judges or standing courts-and here we find the roots of James Wilson's later theory of juries and popular sovereign will. ${ }^{254}$ Even more importantly, however, contemporary English theorists, including Sir William Blackstone, would retain Montesquieu's tripartite structure but graft on a much-enlarged theory of judicial power and practice. ${ }^{255}$ It is this modified English conception, then, that would inform the more radical American approach.

After selling his judicial office in his middle thirties, Montesquieu travelled through Europe studying various political systems. ${ }^{256} \mathrm{He}$ eventually settled in England for two years, where he fraternized with Whig politicians and even earned election to the Royal Society. ${ }^{257}$ It was during this study of English politics that Montesquieu was, in Matthew Bergman's words, "radicalized" by the discovery "that the rule of law and political freedom were practical possibilities." 258 And, across the Atlantic, it was his idealized account of English constitutionalism that became the most cited chapter in The Spirit of the Laws. ${ }^{259}$ In particular, the celebrated passage on dividing political power captured the founding mind:

When the legislative power is united with the executive power in a single person or in a single body of magistracy, there is no lib-

252. See, e.g., Max Radin, Doctrine of the Separation of Powers in the Seventeenth Century Controversies, 86 U. PA. L. Rev. 842, 855 (1937-1938) (quoting Clement Walker, Relations and Observations, Histoicall and Politik upon the Parliament Begun Anno Dom 1640 (1648)).

253. For an excellent assessment of Montesquieu's sparing description of judicial power in England, see Laurence Claus, Montesquieu's Mistakes and the True Meaning of Separation, 25 Oxford J. Legal Stud. 419 (2004).

254. See discussion infra Section II.A.

255. There are a number of excellent books on Montesquieu's influence in late 18th century English legal theory. Three I found particularly useful are: Frank T. H. Fletcher, Montesquieu and English Politics: 1750-1800 (1939); David Lieberman, The Province of Legislation Determined: Legal Theory in Eighteenth-Century Britain (1989); and Paul O. Carrese, The Cloaking of Power: Montesquieu, Blackstone, and the Rise of Judicial Activism (2010).

256. See Bergman, supra note 251 , at 5 .

257. See id.

258. Id. at 6 .

259. See id. 
erty .... Nor is there liberty if the power of judging is not separate from the legislative power and from the executive power .... All would be lost if the same man or body of principal men, either of nobles, or of the people, exercised these three powers[.] $]^{260}$

On the eve of the Philadelphia convention, this sentiment had become all but a truism among leading American theorists. ${ }^{261}$

Montesquieu, however, envisioned the scope of judicial power quite narrowly; in fact, he saw the judges' function as little more than ministerial: "the judges of the nation are . . only the mouth that pronounces the words of the law, inanimate beings who can moderate neither its force nor its rigor." 262 His desire, plainly, was to cabin closely "the power of judging, so terrible among men" in hopes of preventing the sort of arbitrary judicial tyranny that had characterized the English prerogative courts. ${ }^{263}$ In truth, Montesquieu believed judicial discretion would naturally diminish with the emergence of constitutional republicanism:

The more the government approaches a republic, the more the manner of judging becomes fixed .... In despotic states there is no law; the judge himself is the rule. In monarchical states there is law; and, when it is precise, the judge follows it; when it is not, he seeks its spirit. In republican government, it is in the nature of the constitution for judges to follow the letter of the law. No law can be interpreted to the detriment of a citizen when it is a question of his goods, his honor, or his life. ${ }^{264}$

One is certainly hard-pressed to find any hint of American-style judicial review here.

Indeed, Montesquieu envisioned a judiciary without the authority to countermand the other branches of government. ${ }^{265}$ In this sense, the judicial role was formal and mechanistic, never interpretive: "[J]udgments should be fixed to such a degree that they are never anything but a precise text of the law. If judgments were the individual opinion of the judge, one would live in this society without knowing precisely what engagements one has con157.

260. Charles De Secondat, Baron De Montesquieu, supra note 94, at

261. See Paul M. Spurlin, Montesquieu in America 176-80 (1941) (recounting Montesquieu's incorporation into leading university curricula and his reprints in colonial press).

262. Charles De Secondat, Baron De Montesquieu, supra note 94, at 163.

263. Id. at 158 .

264. Id. at 76.

265. See id. at 160; accord Bergman, supra note 251, at 17. 
tracted." ${ }^{266}$ This limitation rendered the judiciary quite weak relative to the other branches: "Among the three powers of which we have spoken, that of judging is in some fashion, null."267 And it was partly for this reason that Montesquieu saw a very limited need for professional or permanent judges, and would instead vest the bulk of judicial authority in ordinary citizens, in a form something like the contemporary English jury. ${ }^{268}$

To this end, he argued that the judicial power "should be exercised by persons drawn from the body of the people at certain times of the year in the manner prescribed by law to form a tribunal which lasts only as long as necessity requires." ${ }^{269}$ But it was not just that the sort of judging Montesquieu recommended required neither education nor expertise. Even more importantly, a jury of peers was a shield against the arbitrary enforcement of laws against particular individuals. The "two other powers may be given instead to magistrates or to permanent bodies," only because "they are exercised upon no individual." 270 Not so the "terrible" power of judging, by which the state's will might be brought to bear directly upon individual citizens. ${ }^{271}$ Again, James Wilson would enthusiastically reaffirm just this sentiment in his account of the American jury. ${ }^{272}$ For this reason, Montesquieu insisted that, "[i]n important accusations, the criminal in cooperation with the law must choose the judges." 273 Further, these must be "of the same condition as the accused, or his peers, so that he does not suppose that he has fallen into the hands of people inclined to do him violence." 274

In delineating a separate and independent judicial power, then, Montesquieu drew a direct connection to the People, even without proposing any particular theory of popular sovereignty. The judicial power, even in the limited and formalistic form he envisioned, functioned as a final safeguard of the People's rights against the coercive power of the state. It was for just this reason that Montesquieu would so severely limit judicial discretion: "No law can be interpreted to the detriment of a citizen when it is a question of his 158.

266. Charles de Secondat, Baron de Montesquieu, supra note 94, at

267. Id. at 160 .

268. See id. at 158; accord Bergman, supra note 251, at 17.

269. Charles de Secondat, Baron de Montesquieu, supra note 94, at 158.

270. $I d$.

271. Id.

272. See discussion infra Section II.A.

273. Charles de Secondat, Baron de Montesquieu, supra note 94, at 158.

274. Id. at $158-59$. 
goods, his honor, or his life." 275 An interpretive judiciary threatened to be every bit as arbitrary and oppressive as any other form of tyranny; and so the point of institutional separation was not so much to empower an additional branch of government, but rather to disempower the executive and legislative branches. The "terrible" power to judge must be emasculated in scope and then situated far from avaricious legislative and executive actors-in the hands of the People themselves. The result, Montesquieu hoped, would be a practical realization of the rule of law.

Back across the channel, English theorists generally accepted Montesquieu's description of a tripartite separation of powers ${ }^{276}$ again, it was consistent with much indigenous thought-but largely ignored his calls for a limited, formalistic judicial function. ${ }^{277}$ This is hardly surprising, given England's rich common law heritage, and the integral role of common law judges as expositors of natural law principles. In particular, Sir William Blackstone-though very much a legislative supremacist_posited quite broad interpretive powers in the professional judiciary. ${ }^{278}$ This power was inherent in common law judging, but perhaps to an even greater degree it underwrote the expansive practice of judicial equity. ${ }^{279}$ With this in mind, Blackstone repeatedly praised the work of Lord Chief Justice Mansfield, the great contemporary reformer who used the common law to modernize outmoded legal forms. ${ }^{280}$ Though neither Blackstone nor Mansfield advocated anything like American-style judicial review, they and like-minded theorists laid a firm foundation for an independent-and powerful-judicial branch. And it was

275. Id. at 76 .

276. Indeed, Blackstone opened his description of the English constitution with a declaration of individual rights seen expressly through the lens of Montesquieu's threefold institutional division. See 1 William Blackstone, CommentaRIES ON THE LAWS OF ENGLAND 136-38 (Univ. of Chi. 1979) [hereinafter Commentaries]. The first three such rights are: (1) to a properly constituted Parliament to prevent laws "destructive of general liberty"; (2) to an Executive limited by law; and (3) to "apply[] to the courts of justice for redress." CARRESE, supra note 255, at 154-55. Blackstone later lays out the tripartite model in language almost identical to Dallison and Montesquieu. See Commentaries, supra, at 259-60.

277. See Lieberman, supra note 255, at 80-90; see also CARrese, supra note 255, at 133-65. Carrese, in particular, notes that the judicial power is given the lengthiest treatment in Blackstone's opening account of the constitution. CARRESE, supra note 255, at 154-55.

278. See CARrese, supra note 255, at 133-65.

279. See Lieberman, supra note 255 , at $83-87$.

280. See generally James Oldham, Judicial Activism in Eighteenth-Century English Common Law in the Time of the Founders, 8 GREen BAG 269 (2005); accord CARRESE, supra note 255, at 152 ("Blackstone's model judge is his contemporary, Lord Mansfield."). 
around these ideas, particularly as expressed in Blackstone's Commentaries on the Laws of England, that the Americans began to build their own ideas about constitutional judging. ${ }^{281}$

Blackstone rejected popular sovereignty theories, and instead located ultimate authority in the King-in-Parliament. ${ }^{282} \mathrm{He}$ thus also rejected recourse to anything like a Lockean "revolution principle."283 As a matter of theory, Blackstone saw the legislative power as uncontrollable in the traditional sovereign sense, and for this reason many commentators suggest that he rejected any limitations on legislative authority. ${ }^{284}$ If this is true, Blackstone repudiated Sir Edward Coke's celebrated opinion in Dr. Bonham's Case, which asserted that common law judges could declare a statute void as "against right and reason." 285 And, in fact, a famous Hobbesian passage in the Commentaries seemed to do just that:

If the parliament will positively enact a thing to be done which is unreasonable, I know of no power in the ordinary forms of the constitution that is vested with authority to control it . . the judges are [not] at liberty to reject it; for that would set the judicial power above the legislature, which would be subversive of all government. ${ }^{286}$

But to accept this statement entirely at face value is to ignore much else that Blackstone had to say about the importance of natural law constraints - particularly the ancient law of the land-and the inherited wisdom of the common law. ${ }^{287}$ David Lieberman has per-

281. See Commentaries, supra note 276. On the Commentaries' impact in America, see, e.g., Daniel Boorstin, The Mysterious Science of Law: An Essay on Blackstone's Commentaries (Univ. of Chi. 1996).

282. See 1 Commentaries, supra note 276, at 46 ("Sovereignty and legislature are indeed convertible terms.").

283. See id. at v. 1, 157. (see discussion supra Section I.A.4).

284. See Lieberman, supra note 255 , at 38 (reviewing literature).

285. Dr. Bonham's Case, (1610) 77 Eng. Rep. 638 (4) (C.P.). Coke was in fact even clearer: "[W]hen an Act of Parliament is against Common right and reason, or repugnant, or impossible to be performed, the Common Law will control it, and adjudge such Act to be void." Id. at (4).

286. 1 COMMENTARIES, supra note 276 , at 91 .

287. The quoted language appears directly below Blackstone's claim that Acts which are "impossible to be performed" or "manifestly contradictory to common reason" are void. 1 COMMENTARIEs, supra note 276, at 91. Blackstone repeats this theme at various times in various ways. See, e.g., id. at v. 1, 41 ("[Natural law] is binding over all the globe, in all countries, and at all times: no human laws are of any validity, if contrary to this; and such of them as are valid derive all their authority mediately or immediately from this original."); see also LIEBERMAN, supra note 255, at 30-55; accord CARRESE, supra note 255, at 156-58 (placing quoted language in context to show that Blackstone recognized that both common law and equitable practice allowed judges to avoid unreasonable results). 
suasively argued that these discussions of legislative constraints are more than the mere "lip-service" Frederick Pollock once claimed, but rather mark the intellectual struggle of a man attempting to reconcile traditional political forms with a growing focus on legal reform and a new "science" of jurisprudence. ${ }^{288}$

With this in mind, Lieberman attributes Blackstone's seemingly absolutist view of parliamentary authority to his larger theory of legislative sovereignty, not to a crabbed conception of the judicial role: "The interpretive mistake is to presume that Blackstone's attitude to parliamentary law-making was fully disclosed in his formal doctrines of constitutional sovereignty." 289 This, of course, is a critical distinction for current purposes, because a popular sovereign paradigm might well produce a different relationship between legislative and judicial institutions. Moreover, faced with dramatic and haphazard legislative proliferation in the decades following the Glorious Revolution, ${ }^{290}$ Blackstone approved of judicial efforts to reconcile or reform defective statutes born of what Jeremy Bentham derided as "the incapacity or inattention of Legislators." 291 In the end, it was the particular genius of the common law systemthe collected wisdom of centuries of judging - that kept the English constitutional system stable and on course.

In this vein, Paul Carrese has undertaken a rich exploration of the "dialectic" Blackstone saw between legislative and judicial lawmaking power. ${ }^{292}$ This is evident, Carrese demonstrates, in the ten celebrated rules of interpretation Blackstone posited as a guide to the common law interpretation of statutes. ${ }^{293}$ These evince a giveand-take that begins with Parliament's authority to supersede the common law by statute. ${ }^{294}$ The courts might then exercise their "initiative" to interpret and apply this legislation, even if bounded by "a severe limit" on the legitimate scope of interpretive discretion. ${ }^{295}$ In this effort, however, the judges were empowered to avoid any "unreasonable" results deemed "not foreseen by parliament"-at which point the dialogue might begin again. ${ }^{296}$ For example, "if an

288. See Lieberman, supra note 255, at 36-52; quotation in Frederick Pollock, A Plea for Historical Interpretation, 39 L. Q. REV. 163, 165 (1923).

289. LIEBERMAN, supra note 255 , at 55.

290. Id. at 13-14.

291. Jeremy Bentham, A Comment on the Commentaries 160 (J.H. Burns \& H.L.A. Hart eds., 1977).

292. See CARrese, supra note 255, at 146, 144-49.

293. See 1 Commentaries, supra note 276 , at 87-91.

294. Id. at 89; accord CARRESE, supra note 255, at 146.

295. CARRESE, supra note 255, at 146.

296. Id. 
Act gives a man power to try all causes that arise in his manor ... the Act [must be] construed not to extend to [a case to which he is a party]; because it is unreasonable that any man should determine his own quarrel." 297 While this dialectic falls well short of wholesale judicial review, it is certainly a substantial upgrade on the interpretive powers Montesquieu described - and we must of course add to this the substantial discretion exercised in the name of judicial equity. ${ }^{298}$

Virtually all of Blackstone's theoretical contemporaries shared his view that equitable practice arose "to correct and soften the rigor of the law, when through its generality it bears too hard in particular cases." 299 Thus, John Fonblanque's seminal A Treatise of Equity declared, "In every well-constituted government there is somewhere lodged a power of supplying that which is defective, and controlling that which is unintentionally harsh, in the application of any general rule to a particular case." 300 This meant, for Blackstone, that equity itself could not be understood as a system of rules, and therefore no positive law existed to constrain judicial discretion "even in those cases where a general pattern of equitable practice pertained." 301 In England, of course, equity was confined, at least formally, to the jurisdiction of specific courts. For many theorists, however, some degree of equitable discretion is inherent in the very nature of all judicial power-though the precise contours of that discretion are still far from clear. ${ }^{302}$ And Blackstone ultimately seems to agree: "Equity then, in its true and genuine meaning, is the spirit of all law: positive law is construed, and rational law is made by it." 303

Blackstone offered this remark, however, as part of his larger effort to defend equity practice against charges of lawlessness. ${ }^{304}$

297. 1 COMMENTARIEs, supra note 276, at 91 .

298. Carrese suggests that we might best read Blackstone as suggesting that common law judges could borrow from equitable practice in some of these discretionary areas. See CARRESE, supra note 255, at 146-48.

299. 1 Commentaries, supra note 276 , at 92 . On contemporary views, see LIEBERMAN, supra note 255, at 74 (citing multiple corroborating sources).

300. Henry Ballow \& John Fonblangue, A Treatise of Equity: Book The First 6 (1737) (3d American ed. 1831).

301. LieBerman, supra note 255, at 75. Lieberman here quotes Blackstone: "Equity thus depending ... upon the particular circumstances of each individual case, there can be no established rules . . laid down . . . ." Id.

302. Id. at 76. Lieberman suggests that "there are few legal topics of the period quite so nebulous as the equitable character of English law." Id. And, as gifted a legal historian as John Langbein has called Blackstone's own attempted account "baffling." Id. at 85.

303. 3 Commentaries, supra note 276 , at 429.

304. Lieberman, supra note 255 , at 84-85. 
This was no easy task within the constitutional sovereignty paradigm he inhabited. If the King-in-Parliament was sovereign and uncontrollable, and the judiciary was a formally independent (thus non-sovereign) branch of government, what justification could exist for an unbounded judicial discretion to remediate or soften the positive law? One tactic, evident in Blackstone's words above, was to distinguish the law's "spirit" from its "letter," and to insist that the judges were bound to the former at all times. ${ }^{305}$ The other, perhaps more common, approach was a reversion to natural law. "[Natural law] is binding over all the globe," Blackstone wrote, "in all countries, and at all times: no human laws are of any validity, if contrary to this." ${ }^{306}$ And so, when an Act of the sovereign (or its application) seemed to violate natural law, it fell to the judge to provide a saving construction, which preserved the Act's status as "law."307 Rather than departing from the law, then, equitable discretion empowered the judge to restore a potentially defective Act to its true and correct legal form. ${ }^{308}$ This was the best Blackstone could do to defend the exercise of broad judicial discretion within the traditional sovereign paradigm. A more perspicuous explanation would have to await the Copernican shift to popular sovereignty.

In both common law and equitable practice, then, Blackstone conceived of an independent judiciary far more powerful than Montesquieu's. In truth, however, Blackstone struggled mightily to reconcile the potentially unbounded scope of judicial discretionparticularly equity - with his notions of parliamentary supremacy and the rule of positive law. Without the innovation of a popular sovereign, and perhaps more pointedly the written constitution, it was difficult indeed to reconcile English judicial practice with the formal doctrines of English constitutionalism. What had made sense when the judiciary operated under the auspices of executive prerogative was perhaps impossible to justify as a matter of independent judicial power. ${ }^{309}$ This was the very tension that the American constitutional model set out to resolve. ${ }^{310}$

305. 1 COMmentaries, supra note 276 , at 429.

306. $I d$. at 41.

307. Id. at 91-92.

308. Id. at 429 .

309. Thus, despite Blackstone's express adoption of Montesquieu's independent judiciary (one not "joined with executive" or put "in the hands of the King's privy council"), 1 COMMENTARIES, supra note 276, at 2601, he still, in places, maintained that "the jurisdiction exercised by [the courts] is derived from the Crown of England, and not from any . . intrinsic authority of their own." Id. at 84 .

310. See, e.g., The Federalist No. 78, at 521-34 (Alexander Hamilton) (Jacob E. Cooke ed., 1961). Indeed, Hamilton lifted passages of this paper almost 


\section{The American Federalists}

In the spring of 1776 , George Wythe and other members of the Continental Congress solicited guidance on constitutional design from Massachusetts's John Adams. ${ }^{311}$ Adams concluded his brief response-which Richard Henry Lee later published as Thoughts on Government - with a soaring rhetorical question:

You and I, my dear friend, have been sent into life at a time when the greatest lawgivers of antiquity would have wished to live .... When, before the present epocha, had three millions of people full power and a fair opportunity to form and establish the wisest and happiest government that human wisdom can contrive? ${ }^{312}$

For Adams, the impending divorce from England promised an escape from the practical corruptions of the ancient constitution, and an opportunity to reform and refine those already excellent institutions without the trappings of aristocratic privilege or imperfect legacies of historical accident. And for James Wilson, the most urgent and important of these reforms must be to first principles:

The dread and redoubtable sovereign, when traced to his ultimate and genuine source, has been found, as he ought to have been found, in the free and independent man. This truth, so simple and natural, and yet so neglected or despised, may be appreciated as the first and fundamental principle in the science of government. 313

In other words, the new nation would be founded on the hitherto "chimerical" basis of popular sovereignty. This political paradigm shift would have profound implications for the American Whigs' notions of judicial power.

\section{A. Popular Sovereignty: James Wilson}

Among the founding generation, no American spoke more often or enthusiastically about popular sovereignty than James Wilson. Born and educated in Scotland, Wilson had become perhaps the nation's preeminent lawyer by the time the Constitution's framers convened in his adopted city of Philadelphia. As such, he would play an integral part in both that framing and the ratification de-

directly from the Commentaries. Cf. id. with 1 COMMENTARIEs, supra note 276, at 259-60.

311. John Adams, Memorandum Preceding Letter to George Wythe of January 1776 (July 21, 1811), available at Founders Online, National Archives, https://bit.ly/ 358jwDu [https://perma.cc/N5MC-H585].

312. Adams, Thoughts on Government, supra note 95, at 200.

313. Wilson, Of the Study of the Law, supra note 14, at 445-46. 
bates to follow. Indeed, Max Farrand identified Wilson as "Madison's ablest supporter" at the Convention; and Bernard Bailyn has suggested that during ratification "it was not so much the Federalist that captured most people's imagination as James Wilson's speech of October 6, 1787, the most famous, to some the most notorious, federalist statement of the time." 314 Just a few months later, in a speech to the Pennsylvania Ratifying Convention, Wilson gave robust voice to a uniquely American conception of popular sovereignty.

While "the great and penetrating mind of Locke" had "pointed towards" the theory of popular sovereignty, it was the American states alone that had actually devised political systems whereby "the supreme, absolute, and uncontrollable authority remains with the people." 315 This was the genius of the written constitutional model:

Sir William Blackstone will tell you, that in Britain the power is lodged in the British Parliament; that the Parliament may alter the form of the government; and that its power is absolute, without control .... To control the power and conduct of the legislature, by an overruling constitution, was an improvement in the science and practice of government reserved to the American states .... [And a]s our constitutions are superior to our legislatures, so the people are superior to our constitutions. ${ }^{316}$

By these innovations, then, Wilson suggested that America had finally put popular sovereignty theory into political practice. Utilizing the most recent advances in political science-most notably the institutional separation of powers-the new nation had finally brought the beast of state under the yoke of its true sovereign master.

To be sure, not all Americans understood the translation from theory to practice in the same terms. ${ }^{317}$ Unlike some others, Wilson came to endorse what we might call a "representative" account of

314. Max Farrand, The Framing of the Constitution 197-98 (1913); Bernard Bailyn, The Ideological Origins of the American Revolution 328 (enlarged ed. 1992).

315. The Debates in the Convention in the Several State Conventions on the Adoption of the Federal Constitution 456 (Jonathan Elliot ed., J.B. Lipincott \& Co. 1881) [hereinafter DeBATEs].

316. Id. at 432.

317. See, e.g., Eric Nelson, Prerogative, Popular Sovereignty, and the American Founding, in Popular Sovereignty in Historical Perspective, supra note 13 , at 187 . 
popular sovereignty and institutional agency. ${ }^{318}$ On this view, it is through representation in the departments of government that the People express their sovereign authority. ${ }^{319}$ Others, perhaps most notably John Adams, held what we might call a "consent" view of popular sovereignty, by which the People could agree at the outset to constitute whatever form of government they chose, even a nonrepresentative monarchy. ${ }^{320}$

Wilson's "representative" conception of popular sovereignty is perhaps clearest in his vision for the American Constitution. In Philadelphia, he argued repeatedly for the popular election of the House, the Senate, and the President. ${ }^{321}$ As he explained during ratification,

A free government has often been compared to a pyramid. This allusion is made with peculiar propriety in the system before you: it is laid on the broad basis of the people; its powers gradually rise, while they are confined, in proportion, as they ascend, until they end in that most permanent of all forms. When you examine all its parts, they will invariably found to preserve that essential mark of free government, a chain of connection with the people. $^{322}$

Wilson, of course, could not convince the Convention to provide for the popular election of the Senate. But this did not stop him from making the even more futile case for a popularly chosen President. Though he knew it sounded "chimerical, ... at least ... in theory he was for an election of [the first magistrate] by the people at large."323 When this suggestion inevitably failed to gain support, he instead proposed a framework for what would become the Electoral College. ${ }^{324}$

Wilson even held to the representative notion that the judiciary should derive its authorization from the People's vote, though his

318. James Wilson, Considerations on the Nature and Extent of the Legislative Authority of the British Parliament, in 1 Collected Works of JAmes WILson, supra note 14, at 3, 3-7 [hereinafter Wilson, Considerations].

319. In his deeply insightful book, Inventing the People, Edmund Morgan makes a compelling case that this account is simply narrative propaganda, and that even during popular elections, wherein "the fiction of popular sovereignty makes its strongest approach to reality," the relationship between voting and any real exercise of popular will or choice was little more than a "charade" in early America. Morgan, supra note 16, at 174.

320. AdAms, supra note 134, at 14.

321. Ian Bartrum, James Wilson and the Moral Foundations of Popular Sovereignty, 64 BufF. L. Rev. 225, 262-66 (2016).

322. Debates, supra note 315, at 524.

323. Remarks of Mr. Wilson (June 1, 1787), in Madison's Notes at 48.

324. Remarks of Mr. Wilson (June 2, 1787), in Madison's Notes at 50. 
failure to secure popular election of the executive would make this connection very attenuated, indeed. ${ }^{325}$ Popular accountability was critical for Wilson, however, because he hoped to create a combined executive and judicial council with substantial powers of legislative revision:

The Judiciary ought to have an opportunity of remonstrating ag'st projected encroachments on the people as well as on themselves .... Laws may be unjust, may be unwise, may be dangerous, may be destructive, and yet may not be so unconstitutional as to justify the Judges in refusing to give them effect. Let them have the Revisionary power, and they will have an opportunity of taking notice of these characters of a law. ${ }^{326}$

But, even as he failed to convince the Convention to adopt the Council of Revision, Wilson remained a staunch supporter of Article III judicial review as a safeguard of the people's sovereign will. ${ }^{327}$

Indeed, it was ultimately to the courts that Wilson would entrust institutional, legalized guardianship of Locke's abstract right of revolution. ${ }^{328}$ In his Lectures on Law, Wilson asserted that a socalled "revolution principle certainly is, and certainly should be taught as a principle of the constitution of the United States and of every state in the Union." 329 He adamantly rejected Blackstone's infamous assertion that such a view would "destroy all law":330

The revolution principle-that the sovereign power residing in the people; they may change their constitution and government whenever they please-is not a principle of discord, rancor, or war; it is a principle of melioration, contentment, and peace. It is a principle not recommended merely by happy flattery; it is a principle recommended by happy experience. ${ }^{331}$

325. Bartrum, supra note 321, at 265.

326. Remarks of Mr. Wilson (July 21, 1787), in MAdison's Notes, at 336-37.

327. Indeed, as Associate Justice, Wilson would have beaten Marshall to the proverbial punch had Congress not voluntarily revised the statute at issue in the first Hayburn's Case. For a full discussion, see Max Farrand, The First Hayburn Case, 13 Ам. Hist. Rev. 281 (1908).

328. For fuller discussion of these ideas, see Aaron T. Knapp, Law's Revolutionary: James Wilson and the Birth of an American Jurisprudence, 29 J.L. \& PoL. 189 (2014); see Bartrum, supra note 321, at 279.

329. Wilson, Of the Study of the Law, supra note 14, at 443 (emphasis added).

330. 1 Commentaries, supra note 276 , at 162 (quoted in Wilson, Of the Study of the Law, supra note 14, at 441).

331. Wilson, Of the Study of the Law, supra note 14, at 443. 
The judicial institution that Wilson saw bringing this theoretical principle to practical life was the American jury. ${ }^{332}$

It was the jury, Wilson believed, that served as the most basic repository of popular sovereign discretion. "In all states," he wrote, "discretionary powers must be placed somewhere. The great body of the people is their permanent depository. But on some occasions, and for some purposes, they must be delegated." 333 When placed in juries, as "nature and original justice" recommend, ${ }^{334}$ this authority is "one of the greatest blessings- . . one of the greatest securities-which can be enjoyed under any government." 335 Indeed, the American system entrusted the jury with the "tremendous" authority—one "interdicted even to the legislature[ ]"-of applying the law to the world with individual particularity: "Neither congress nor the general assembly of this commonwealth, can pass any act of attainder for treason or felony." 336 Only the sovereign itself, instantiated in the jury, could decide an individual's fate before the law. What better recourse to the source of sovereign authority than to give the People the final word on the law's practical application? ${ }^{337}$

This idea is consistent with Wilson's overall representative conception of practical popular sovereignty. Describing the necessity of a broadly representational legislature at the Convention, he claimed,

The Gov't ought to possess not only the force, but 2dly the mind or sense of the people at large. The Legislature ought to be the most exact transcript of the whole Society. Representation is made necessary only because it is impossible for the people to act collectively. ${ }^{338}$

For Wilson, again, popular sovereignty is manifest in elections and something like mimetic representation. Thus, the jury's institutional claim to a share of the sovereign prerogative is its democratic bona fides-it is, quite literally, a random sampling of the sovereign power itself. Again, this conception would put Wilson at odds with men like Adams, who maintained that the delegated institutions of

332. James Wilson, The Subject Continued, Of Juries, in 2 Collected WORKS OF JAMES WILsON, supra note 14, at 954, 955-62.

333. Id. at 961.

334. Id. at 963.

335. James Wilson, Comparison of the United States, With That of Great Britain, in 1 Collected Works of James Wilson, supra note 14, at 718, 745.

336. Wilson, The Subject Continued, Of Juries, supra note 332, at 954, 1009. $282-83$.

337. For an earlier version of this paragraph, see Bartrum, supra note 321, at

338. Remarks of Mr. Wilson (June 6, 1787) in Madison's Notes at 74. 
sovereignty could take whatever form the People chose, so long as duly authorized in a ratified constitution. ${ }^{339}$

In truth, it is perhaps ironic that, despite Wilson's rhetorical alliance with Locke, both he and Adams initially endorsed something much closer to a Hobbesian-or a modified Royalist-account of social contract theory. ${ }^{340}$ Early in his revolutionary discourse Wilson, like many Americans, took issue with Parliament's — not the King's — claims to absolute authority. ${ }^{341}$ Rejecting claims of consent based in "virtual representation," 342 Wilson and others reasoned that the King alone enjoyed the requisite authority to represent the people's sovereign will. ${ }^{343}$ Wilson even resurrected the King's dreaded "negative prerogative" as a potential refuge for Americans against parliamentary overreach. ${ }^{344}$ It was only in response to suggestions that this Royalist conception of sovereign unity could not account for sustained popular dissent that Wilson fully developed his "representative" account of institutional legitimacy. ${ }^{345}$ And, in the end, this account provides shaky grounds indeed for locating a sweeping judicial power in a largely unrepresentative Supreme Court. It would be left, then, to Adams-and his insights into the separation of consensually delegated powers - to justify our decision to unbundle the sticks of traditional sovereign power, and to lodge a revolutionary prerogative in an independent judiciary.

\section{B. Separation of Powers: Adams and Hamilton}

In the opening chapter of his groundbreaking book The Creation of the American Republic, Gordon Wood emphasizes the American revolutionaries' reverence for the English constitution. ${ }^{346}$ No less a figure than John Adams declared in 1761 that "[n]o government that ever existed was so essentially free."347 To the Whig colonials, then, opposition to the mother country was about perfect-

339. John Adams, Defence of the Constitutions of Government of the United States, in 6 Works of John Adams, supra note 95, at 2, 146 [hereinafter Adams, Defence].

340. Nelson, supra note 317, at 198-200. On Hobbes's differences with the Royalist account, see discussion supra Section I.A.4.

341. Nelson, supra note 317, at 190-94.

342. Id. at 196-98.

343. Id. at 192-93.

344. Wilson, Considerations, supra note 318, at 30.

345. Nelson, supra note 317, at 208-10.

346. Wood, Creation, supra note 171 , at 10-28.

347. Id. at 11 . 
ing-not abandoning - the ancient English structures. ${ }^{348}$ As Wood observes, "They sincerely believed they were not creating new rights or new principles, but saw themselves claiming 'only to keep their old privileges,' the traditional rights and principles of all Englishmen, sanctioned by what they thought has always been."349 And so when Adams sat down to devise distinctly American forms of government, he first planned to,

[S]tudy the law of nature; search into the spirit of the British constitution; read the histories of ancient ages; contemplate the great examples of Greece and Rome; [and] set before [myself] the conduct of our own British ancestors, who have defended for us the inherent rights of mankind against foreign and domestic tyrants and usurpers ...350

Adams and fellow anglophile Alexander Hamilton would then do as much as anyone to preserve the basic architecture of the English constitution, even while reconciling it to the emergent popular sovereignty paradigm. This final subsection explores the results of that effort for American judicial power.

In February of 1761, Boston lawyer James Otis appeared before the Massachusetts Superior Court to challenge a century old British statute authorizing the court to issue writs of assistance for the general search of colonial homes. ${ }^{351}$ Citing, inter alia, Coke's decision in Dr. Bonham's Case, Otis made one of the first American arguments for judicial review of an Act of Parliament:"352 "An act against the constitution is void; an act against natural equity is void; and if an Act of Parliament should be made in the very words of this petition, it would be void. The executive Courts must pass such acts into disuse." 353 His reference to the "executive Courts" belies Otis's appeal to the dependent judicial structure of the ancient constitution, to which, again, most colonists still turned for

348. Id. at 13. Indeed, it was the internal corruption of the English constitution that the Whigs set themselves against. Id.

349. Id. (quoting John Adams, Novanglus, in 4 Works of John Adams, supra note 95 , at 11,131$)$.

350. John Adams, Dissertation on the Canon and Feudal Law, in 3 Works of John Adams, supra note 95, at 445, 462.

351. M.H. Smith, The Writs of Assistance Case 312 (1978).

352. On Coke, see id. at 485. On judicial review, see Gerber, supra note 4, at 91. Gerber notes two earlier arguments for judicial review in South Carolina. $I d$. at n.86.

353. James Otis, Speech in the Writs of Assistance Case, (Feb. 24, 1761), in 2 Works of John Adams, supra note 95, at 522. 
vindication. Otis succeeded in getting a temporary delay from the court, but he eventually lost the case. ${ }^{354}$

John Adams was in the gallery that afternoon and would later recall how "great an influence [the incident had] over his subsequent career."355 Otis's argument, and its rejection, made clear to Adams, for perhaps the first time, that revolution was inevitable: "A contest appeared to me to be opened, to which I could foresee no end, and which would render my life a burden, and property, industry, and everything insecure."356 Indeed, Adams would later claim the corruption was so deep that Chief Justice Thomas Hutchison had received his judicial commission specifically so that he might uphold the dubious writs. ${ }^{357}$ So alienated had the English administration grown from the natural law and its own first principles that, for Adams, a "collision" with the colonial conscience was unavoidable. ${ }^{358}$ The American Whigs could never accept the second-class status Parliament pressed upon them, and Adams vowed "to die . . . with a decent grace, should that trial become inevitable." 359

Still, he did not yet conceive of the crisis in terms of constitutional design, and even five years later he spoke approvingly of the executive court paradigm. ${ }^{360}$ By 1773, however, when Adams disputed Loyalist General William Brattle in the pages of the Boston Gazette, his support for greater judicial independence had become clear. In a series of essays, Adams responded to Brattle's efforts to dispel fears about the King's decision to put the judges of the Massachusetts Superior Court on the royal payroll. ${ }^{361}$ Both in oration and in print, Brattle had claimed that the colonial judges would hold their offices during good behavior "as the judges of England have their salaries granted them," which would render them "independent both upon the king and the people."362 It was of no mo-

354. SMITH, supra note 351 , at 430-35.

355. John Adams, Diary: With Passages from an Autobiography, in 2 Works of John Adams, supra note 95, at 1, 124 n.1 [hereinafter Adams, Diary]. For more on Adams's involvement and reaction to the case, see Sмітн, supra note 351, at $135-42$.

356. Adams, Diary, supra note 355, at 1, 124 n.1.

357. Sмiтh, supra note 351 , at 136.

358. Adams, Diary, supra note 355, at 1, 124 n.1

359. Id.

360. Gerber, supra note 4, at 91.

361. Editorial Note, in 1 Papers of John Adams 252, 252-55 (Robert J. Taylor et al. eds., Harvard Univ. Press 1977), https://bit.ly/3jPPMQp [https://perma.cc/ TZT4-UXS6].

362. William Brattle, To the Printers, Massachusetts Gazette (Jan. 4, 1773), in 3 Works of JoHn AdAms, supra note 95, at 516, 517. 
ment, Brattle argued, that there were no statutory assurances of this protection, because "the common law of England" had long assumed the lifetime tenure of judges. ${ }^{363}$ He then challenged anyone "who had leisure" to dispute his legal claims. ${ }^{364}$

Always an eager combatant, Adams took up that challenge in a series of seven published essays. ${ }^{365}$ In typical fashion, he produced an avalanche of quotations demonstrating that tenure during good behavior was a recent statutory development, applicable only in England, ${ }^{366}$ with no appreciable roots in the common law. ${ }^{367}$ Indeed, he suggested that one need look no further than the arbitrary removal of so celebrated a jurist as Sir Edward Coke, or King James II's subsequent decision to remove Coke's replacement and three others, to understand that judges traditionally served at the Crown's pleasure. ${ }^{368}$ Of the latter removals Adams wrote, "There is not in history a more terrible example of judges perishing at the royal nod than this, nor a stronger evidence that the power and prerogative of removing judges at pleasure were allowed to be, by law, in the crown."369 And, while Parliament had recently acted to better protect judicial independence at home, it was still happy to foist the unfortunate executive court paradigm upon the colonies. This, Adams would argue moving forward, was a structural failing that Americans must redress in crafting their own constitutions.

This was a central argument in Thoughts on Government, Adams's broadly influential response to George Wythe's inquiries on constitutional design. ${ }^{370}$ "The dignity and stability of government in all its branches . . . depend so much upon an upright and skillful administration of justice," he began,

[T]hat the judicial power ought to be distinct from both the legislative and executive, and independent upon both, that so it may

363. Id. at 527, 518 ("These points of law have been settled and determined by the greatest sages of the law, formerly and more lately.").

364. Editorial Note, supra note 361, at 254.

365. The entire series can be found under the title On the Independence of the Judiciary in 3 Works OF JoHN AdAms, supra note 95, at 519-74.

366. Id. at 520 ("The power of the crown to grant salaries to any judges in America is derived solely from the late act of parliament, and that gives no power to grant salaries for life or during good behavior.").

367. See id. at 527-28 (quoting Blackstone's claim that a recent statute-13 W. III. c. 2-provided that judicial "commissions shall be made, not, as formerly, durante bene placito [at pleasure], but quamdiu se bene gesserint [during good behavior]").

368. Id. at 528,530 .

369. Id. at 529 .

370. See David McCullough, John Adams 103 (2001) ("Little that Adams ever wrote had such effect as his Thoughts on Government."). 
be a check upon both, as both should be checks upon that. The judges, therefore, ... should not be dependent upon any man, or body of men. To these ends, they should hold estates for life in their offices; or, in other words, their commissions should be during good behavior, and their salaries ascertained and established by law. ${ }^{371}$

Adams's disseminated his pamphlet widely in the winter and spring of 1776, as the American colonies anticipated the break with England and began to devise independent constitutional forms of their own. ${ }^{372}$ In his own Massachusetts, such an effort had been underway since the spring of 1775 , though an official committee was not empaneled for another two years. ${ }^{373}$ After a 1778 proposal failed to gain sufficient popular support, there was some doubt whether the public would favor any permanent form of government at all. ${ }^{374} \mathrm{By}$ the fall of 1779, however, a convention of delegates met in Boston for the exclusive purpose of forming a state constitution. ${ }^{375}$

Adams himself wrote the initial draft of the Massachusetts Constitution of 1780 , which some hold out as the oldest written charter in the world. ${ }^{376}$ Even in its Preamble, the draft identified a "duty" to structure republican government around the three fundamental powers, thus "to provide for an equitable mode of making laws, as well as for an impartial interpretation and faithful execution of them."377 And in the immediately subsequent Declaration of Rights, Adams included the newly ascendant principle of popular sovereignty, ${ }^{378}$ Locke's revolution principle, ${ }^{379}$ and the essential

371. Adams, Thoughts on Government, supra note 95, at 198. Adams repeated this passage verbatim in a subsequent response to a North Carolina delegation's request for assistance. John Adams, To John Penn, in 4 Works of JoHN AdAms, supra note 95, at 203.

372. Editorial Notes, in 4 Works of John Adams, supra note 95, at 190.

373. Charles F. Adams, Observations on the Reconstruction of Government in Massachusetts During the Revolution, in 4 Works of John Adams, supra note 95, at $212,213-14$.

374. Id. at 215.

375. Id.

376. Id. Adams joined his cousin Samuel and Judge James Bowdoin on the sub-committee chosen to draft the document; the sub-committee then assigned the task to Adams alone. Id. On the Massachusetts Constitution of 1780, see GERBER, supra note 4, at 87.

377. The Report of a Constitution, or Form of Government, for the Commonwealth of Massachusetts, Preamble, in 4 Works of JoHn AdAMs, supra note 95, at 219, 219-20.

378. Id. art. V ("All power residing originally in the people ... the several magistrates and officers ... are their substitutes and agents . ...").

379. Id. art. VII ("[T] he people alone have an incontestable, unalienable, and indefeasible right to institute government; and to reform, alter, or totally change the same."). 
right to an independent judiciary. ${ }^{380}$ On the latter point, he hoped to codify his response to Wythe:

It is essential to the preservation of the rights of every individual, his life, liberty, property, and character, that there be an impartial interpretation of the laws, and administration of justice. It is the right of every citizen to be tried by judges as free, impartial, and independent as the lot of humanity will admit. It is, therefore, not only the best policy, but for the security of the rights of the people and of every citizen, that the judges should hold their offices as long as they behave themselves well, and that they should have honorable salaries ascertained and established by standing laws. ${ }^{381}$

Significantly, Adams here affirmatively made the institutional step that Locke had been unwilling to take a century earlier: An independent judiciary must serve as the neutral third-party for appeals to the rights reserved from the social contract. ${ }^{382}$

In this way, then, Adams presaged James Wilson's argument for institutionalizing Locke's revolution principle within the courts-with one very significant difference. ${ }^{383}$ Where Wilson's reliance on the "representative" conception of popular sovereignty forced him to locate the revolutionary prerogative in juries, Adams's popular "consent" model enabled him to vest it in constitutional judges. He made this case in his Defence of the Constitutions of the Governments of the United States, published in 1787 during his ambassadorship in London.

Adams began by challenging a maxim credited to Marchmont Nedham: "[T] he people, (that is, such as shall be successively chosen to represent the people) are the best keepers of their own liberties ... because they never think of usurping over other men's rights, but mind which way to preserve their own." ${ }^{84}$ Even accepting Nedham's "confus[ed]" definition of the People, Adams argued that a representative assembly are, in fact, "not the best keepers of the people's liberties or their own, if you give them all the power, legislative, executive, and judicial." 385 Without an institutional separation of powers, he claimed "a majority . . . would invade the liberties of the minority sooner and deeper than an abso-

380. Id. art. XXIX-XXX.

381. Id. art. XXX.

382. See discussion supra notes $87-88$ (arguing that this appeal must be made to God in the form of revolution).

383. See discussion supra notes 337-39 (on juries and revolution principle).

384. Adams, Defence, supra note 339 , at 2, 6 .

385. Id. at 7 (emphasis supplied). 
lute monarchy." 386 Indeed, Nedham's conclusion-that the people "never think of usurping over other men's rights"-was patently absurd and only begged the question "[then] what occasion can there be for government at all?" Rather, Adams suggested, Nedham's proposition should be reversed to say that majorities "mind so much their own [rights], that they never think enough of others." 387 In truth, the popular sovereign promised to be every bit as tyrannical as any despot without the constraints of a divided institutional structure. ${ }^{388}$

For Adams, the problem with Wilson's "representative" conception of popular sovereign governance, then, is that it fails to account for minority interests and rights in any systematic way. In fact, while representation is valuable, it is not essential-and on its own could hardly deliver on the promise of a stable republican government. Rather, Adams endorsed a quasi-Hobbesian model grounded in a recognized moment of popular consent:

If the original and fountain of all power and government is in the people, as undoubtedly it is, the people have as clear a right to erect a simple monarchy, aristocracy, or democracy, or an equal mixture, or any mixture of the three, if they judge it for their liberty, happiness, and prosperity, as they have to erect a democracy ... . 389

Democratic representation, in other words, is not the legitimating feature of a government grounded in popular sovereignty. What matters is the consensual delegation of the People's sovereign powers - in whatever form or admixture-to a particular arrangement of political institutions. With that said, the People also retain the sovereign right to withdraw that consent at any time and start over: "[T]he same people have at all times a right to interpose, and to depose for maladministration-to appoint anew." ${ }^{390}$ If quasiHobbesian on the front end, then, Adams's vision was expressly Lockean on the back end.

To return to the property law analogies prevalent in the popular sovereignty literature, ${ }^{391}$ Adams's account lends itself easily to the "bundle of sticks" trope often used to describe property rights. In this context, we might think of these sticks as representing various sovereign powers and prerogatives, which might be distributed

386. $I d$.

387. Id. at 8 .

388. Id.

389. Id. at 117.

390. $I d$.

391. See discussion supra I.A.3. 
to various institutions in various ways, perhaps with certain future interests contingent upon conditions subsequent. ${ }^{392}$ In the state of nature, the People hold the entire bundle of sovereign prerogatives, which, through a ratified constitutional agreement, they may delegate as they see fit. As discussed in the introduction, Michael McConnell has done remarkable work detailing the negotiated allocation of these sticks between the executive and legislative branches. $^{393}$ I suggest that we can fairly infer from Adams that the sovereign prerogative to declare breaches of the delegation agreement itself - to announce the constitutional law of the land-fell to the judiciary. For Adams it was not necessary, as Wilson argued, to lodge this revolutionary prerogative in a representative judicial body like the jury, so long as the People consented to lodge it somewhere. Of course, the People always retain the right to reclaim this prerogative through constitutional amendment or dissolution, but to take either of these steps is to enter the state of exception-and so, in the United States, the Supreme Court represents the final intra vires appeal to the rule of constitutional law.

Like Adams, Alexander Hamilton had great admiration for the English constitution, whose "fundamental principles," he argued, "are in our favor." $394 \mathrm{He}$, too, initially adopted a quasi-Royalist position, whereby Americans owed no fealty to the English legislature: "[W]e may pronounce it a matter of undeniable certainty, that the pretensions of Parliament are contradictory to the law of nature, subversive of the British constitution, and destructive of the most solemn compacts." 395 It was this last treachery-the breach of the sovereign social contract - that would eventually enable Hamilton to make a full-throated defense of judicial review, even over many contemporary Whig objections. ${ }^{396}$ After all, the popular sovereign model, with its concomitant notions of limited government, required some institutionalized protection for the constitutional

392. The trope is thought to have roots in Blackstone, with later refinements by Wesley Newcomb Hohfeld and Tony Honoré. See, e.g., Abraham Bell \& Gideon Parchomovsky, A Theory of Property, 90 Corn. L. REv. 531, 543-47 (2005).

393. See McConnell, supra note 1.

394. Alexander Hamilton, A Full Vindication of the Measures of Congress (Dec. 15, 1774), reprinted in 2 The Works of Alexander Hamilton 1, 3 (John C. Hamilton ed., 1850).

395. $I d$. at 6-7.

396. See Wood, Creation, supra note 171, at 455-64 (recounting objections to and defenses of judicial review). 
contract itself. ${ }^{397}$ It was this popular sovereign paradigm shift, rooted not in representative institutions, but in Adamsian notions of consent, that made Hamilton's view possible. In Gordon Woods's words,

What made such a judicial power comprehensible, Hamilton acutely realized, was the changed relation that had taken place between the people and their supposed representatives in the legislature. The representatives of the people were not really the people, but only the servants of the people with a limited delegation authority to act on behalf of the people. ${ }^{398}$

For Hamilton, this meant that some "intermediate body" must judge the terms of the People's sovereign delegation to their temporary political agents. ${ }^{399}$ In Federalist 78, Hamilton laid out the institutionalization of this revolutionary prerogative in what Wood identifies as "the most concise and frank defense of judicial review [written] in the 1780's." 400

Though much has been made of Hamilton's description therein of the judiciary as "the least dangerous" branch, it was precisely the Court's worldly weakness that made it the ideal repository of the remarkable revolutionary prerogative. ${ }^{401}$ That prerogative itself, if joined with executive or legislative prerogatives, would give republican liberty "every thing to fear." ${ }^{402}$ Indeed, Hamilton understood Montesquieu's (whom he cited directly) concerns about the "terrible" power of judging, and echoed the latter's desire to cabin this authority far from the powers of purse or sword. ${ }^{403}$ Thus, it was not the essence of the new judicial power that was weak or impotent, it was only that the Court lacked practical mechanisms to enforce its substantial decision-making authority. It was, in fact, the potentially broad sweep of the discretion lodged in the courts that made factional independence so vital within "the citadel of the public justice and public security." ${ }^{04}$ With this in mind, Hamilton's primary

397. Id. at 462 ("But since the American governments were limited, the judiciary must also defend the constitution against violations by other departments, particularly the legislature.").

398. Id. (emphasis added).

399. The Federalist No. 78, supra note 310, at 525.

400. Wood, Creation, supra note 171, at 462.

401. Alexander Bickel's ironical title is perhaps most responsible for the phrase's fame-even if the book itself is an underwhelming piece of constitutional theory. Alexander M. Bickel, The Least Dangerous Branch: The Supreme Court at the Bar of Politics (1963).

402. The Federalist No. 78, supra note 310, at 523.

403. Id. at 523 .

404. Id. at 523-34. 
purpose in Federalist 78 was to explain the structural necessity of delegating this extraordinary prerogative to the judicial branch.

The explanation he provided could hardly be a clearer statement of the Court's institutional role as neutral arbiter of the Lockean revolutionary appeal. Thus, the constitutional limits placed on the People's delegations to the political branches,

. . . can be preserved in practice in no other way than through the medium of the courts of justice; whose duty it must be to declare all acts contrary to the manifest tenor of the constitution void. Without this, all reservations of particular rights or privileges would amount to nothing. ${ }^{405}$

Hamilton was certainly aware that judicial review of this kind might "imply a superiority of the judiciary to the legislative power," which both Hobbes ${ }^{406}$ and Blackstone ${ }^{407}$ had found unacceptable. He pointed out, however, that this objection is entirely inapposite within the new popular sovereign paradigm, which "only supposes that the power of the people is superior to both; and that where the will of the legislature declared in its statutes, stands in opposition to that of the people declared in the constitution, the judges ought to be governed by the latter." 408 It is simply not the case, as Hobbes supposed, that only one of these institutions can be sovereign; rather, the People may contingently empower both institutions to exercise different sovereign prerogatives.

Hamilton further explained why the courts must be the sole delegated repository of the revolutionary prerogative:

If it be said that the legislative body are themselves the constitutional judges of their own powers, and that the construction they put upon them is conclusive upon other departments, it may be answered that this cannot be the natural presumption .... It is not otherwise supposed that the constitution could intend to enable the representatives of the people to substitute their will to that of their constituents. It is far more rational to suppose that the courts were designed to be an intermediate body between the people and the legislature, in order . . to keep the latter within the limits assigned to their authority. The interpretation of the laws is the proper and peculiar province of the courts. ${ }^{409}$

405. Id. at 524 .

406. See discussion supra I.A.4

407. See discussion supra I.B.3.

408. The Federalist No. 78, supra note 310, at 525.

409. Id. at 524-25 (emphasis supplied). 
While Hamilton here addressed judicial authority vis-à-vis the legislature, his arguments apply with equal perspicuity and force against the executive branch. Unless and until the People withdraw the revolutionary prerogative, it remains entirely committed to the judiciary.

It was the American Whigs, then, that took the final theoretical and institutional steps necessary to put the idea of popular sovereignty into political practice through the mechanism of constitutionally separated powers. James Wilson understood that a true popular sovereign structure requires some institutionalized appeal of the social contract itself, and that the Lockean revolution principle "certainly is, and certainly should be taught as, a principle of the constitution of the United States." ${ }^{410}$ While he placed that principle in the judiciary's charge, his representative conception of popular sovereignty forced him to lodge the prerogative in juries, rather than judges. John Adams likewise recognized the fundamental necessity of Locke's principle, but his consent-based account of popular sovereignty allowed him to unbundle the sticks of sovereign prerogative, and to vest the courts themselves with the authority to declare the People's sovereign will. And finally, in Federalist 78, Alexander Hamilton made the clear and concise case for the institutional mechanics of all this in the doctrine of judicial review, which locates final intra vires interpretive discretion in the Supreme Court. Centuries of evolving thought about popular sovereignty and the separation of powers had finally merged in the creation of a uniquely American conception of judicial power. ${ }^{411}$

\section{ConClusion}

The American judicial prerogative-what I have called here the "revolutionary prerogative"-represents a synthesis of political ideas that developed over two millennia of human experience and institutional innovation. In particular, the long-evolving doctrines of popular sovereignty and the separation of powers came together

410. Wilson, Of the Study of the Law, supra note 14, at 443.

411. I have tried to indicate throughout that this is a distinctly Whiggish history of American constitutional structure. As noted above, more Republican voices-most notably Jefferson and Madison-were much less trusting of judges, and much more willing to take a "departmentalist" view of judicial review. Without discounting these distinct strands of constitutional thought, my view is that the Whig conceptions make much better sense of the popular sovereign structural model, and are more consistent with the predominant developments in English and continental political theory over the previous centuries. Whig conceptions would largely carry the day in early American practice, as well, though this must be the subject of future work. 
in a distinctly American constitutional structure. Popular sovereignty theorists like Marsilius and Jean Bodin distinguished between the concepts of sovereignty and government, and located ultimate political authority in the People themselves. In early Enlightenment England, Thomas Hobbes and John Locke theorized that the People delegate sovereign authority to their political agents through a social contract and, in Locke's account, may withdraw that authority at any time through dissolution or revolution. Separation of powers doctrine, with origins in Aristotle's classical mixed regime, developed during the English Civil War into the institutional division of three separate political functions: legislation, judgment, and execution. In the years leading up to the American founding, William Blackstone struggled to reconcile the newly independent English courts-with their common law discretion and equitable powers - to traditional notions of constitutional sovereignty and legislative supremacy. The Americans would ultimately resolve this tension by incorporating separation of powers doctrine into the popular sovereign paradigm.

James Wilson was the most prominent expositor of popular sovereignty during the American founding. Taking an essentially Lockean approach, he repeatedly emphasized the importance of institutionalizing the so-called "revolution principle"-the People's right to appeal violations of the social contract-within the constitutional structure. While Wilson recognized the judiciary as the natural locus of this appeal, his "representative" conception of popular sovereignty led him to vest this discretion in juries, rather than courts. John Adams, however, rooted popular sovereign legitimacy in the People's ratifying "consent" to a constitutional scheme. This conception permits the People to divide the sticks of sovereign prerogative in various ways, including among separate legislative, judicial, and executive branches. Adams then argued that an independent judiciary, comprised of life-tenured judges, is best positioned to exercise the revolutionary prerogative to declare that government has exceeded its delegated authority. Finally, in Federalist 78, Alexander Hamilton explained how popular sovereignty resolves Blackstone's legislative supremacy dilemma, and why the judiciary alone must decide any disputes over the People's constitutionally limited delegations of authority.

The late Charles Black once observed that appeals to constitutional structure may not decrease the frequency or vehemence of our legal disagreements, but, he suggested, "at least we would be differing on exactly the right thing, and that is no small gain in the 
law." ${ }^{412}$ Before we begin disagreeing about how or why structural considerations should inform actual legal controversies, however, it is important simply to understand the structure itself as well as we can. That has been my goal here-to take a fresh look at the theoretical bricks fired over centuries of political thought, and to appreciate how early Americans laid these bricks to construct new constitutional forms. That construction did not end at the founding, of course, and there is much more to say about the ways that our ongoing constitutional practice has reshaped our understandings. Indeed, the formative impact of that practice over the first three decades of American political life is the subject of my next study. ${ }^{413}$ For now, though, I hope I have helped to clarify and justify the constitutional ideas that first delegated to Article III judges the revolutionary prerogative of judicial review.

412. Charles L. Black, Jr., Structure and Relationship in ConstituTIONAL LAW 48-49 (1969).

413. This practice includes not just the Marshall Court's formative decisions, but also the popular adoption of corporate principles from the English charter model, which structured early colonial governance in many places. See, e.g., Mary Sarah Bilder, The Transatlantic Constitution: Colonial Legal CulTURE AND THE EMPIRE (2004); Mary Sarah Bilder, The Corporate Origins of Judicial Review, 116 Yale L.J. 502 (2006); Akhil Reed Amar, Of Sovereignty and Federalism, 96 YAle L.J. 1425 (1987). 